\title{
The Phenotype Expression, Taxa Level and Traits Configuration of Moluccas Ring Cowrie, Cypraea Annulus (Gastropod: Cypraeidae)
} Based on Morphometric Traits data

\section{Bruri Melky Laimeheriwa1,2,3*, Imagodeo Bideyesa ${ }^{3,4}$ and Misiodei}

\section{de Gospel ${ }^{3,4}$}

${ }^{1}$ Departement of Aquaculture, Faculty of Fisheries and Marine Science, Pattimura University, Indonesia

2Maritime and Marine Science Center of Excellence, Pattimura University, Indonesia

${ }^{3}$ Computational Biology Studios, Penabur Computech Ambon, Indonesia

${ }^{4}$ SMA Negeri 5 Ambon, Maluku, Indonesia

${ }^{*}$ Corresponding author: Bruri Melky Laimeheriwa, Department of Aquaculture, Faculty of Fisheries and Marine Science, Pattimura University, Ambon, Indonesia, Email: bruripenabur@gmail.com

\section{Abstract}

Knowledge and understanding of phenotype expression, the taxa level, the traits configuration among sub-populations play a role in monitoring and evaluation of biota performance, selection and hybridization programs. This study aimed to investigate phenotype expression, to determine the taxa level and to map the trait configuration between 32 subpopulations of the Moluccas ring cowrie (MRC), Cypraea annulus based on three data types of morphometric trait. Cypraea annulus samples were used as many as 2926 specimens from 32 subpopulations and 104 test traits. Observation and measurement of morphometric traits done in macrometry and micrometry for three data types namely binary, ordinal and numeric. The results of this study indicate that 32 sub-populations of MRC had various phenotype expressions of morphometric (PEM) for binary and ordinal data types with the highest coefficient values in the range of 0.85 to 0.89 for binary data types and 0.80 to 0.84 for ordinal data types, whereas for numerical data types Its expression was homogeneous with the highest value range 0.95 - 1.00. The morphometric taxa level (MTL) for the binary data type obtained 17 taxa at 70\% similarity level; ordinal data type obtained 19 taxa at correlation level 0,700 and numeric data type obtained one taxon at correlation level 0,970. The map of morphometric trait configuration (MTC) of the MRC trait derived four trait classes for binary data types and three trait classes for ordinal and numeric data types. The different variations of PEM and MTL proved that the expression of morphometric proportions of the MRC was strongly influenced 


\section{International Journal of Oceanography \& Aquaculture}

by the environment, lifetime and life stages of snails. In addition, the proximity of the similarity of expression between the 32 sub-populations, although living in a geographical location, lifetime and stage of development of different living.

Keywords: Phenotype; Expression; Taxa; Traits; Configuration; Morphometric; Cypraea; Cowrie

\section{Introduction}

In the genetic concept, each species is a genuine population and each individual can mix with its species populations [1-3]. This mixing leads to the emergence of phenotypic variation of individual traits and increases in proportion to the increasing population distribution area [4-8]. Although the expression and performance of the traits of each biota vary, the performance of an individual's trait has a unique and specific pattern of order [9-11]. By recognizing and analyzing these patterns of order, they can serve as individual trait entities in their species populations [12-14].

Phenotypic expression of morphometrics (PEM) is the expression of traits related to variation and changes in the size of the body's shape and structure of the organism or measured methods [15-17]. Morphometric traits (MT) measure the traits on certain parts of the organism's body surface either or with the help of software $[18,15,19]$. Each individual has a specific and different size between one organism and another in the same age group $[20,3,21]$. Measurements of MT used to measure specific features and variation relationships in a population stock of marine biota $[22,20,23]$. MT size is an absolute size and the size ratio depends on the purpose of measurement. The unit of measure used for the purposes of taxonomy and identification is a measure of comparison, whereas for the assessment and monitoring of individual conditions and status used units of absolute size [24-28].

Moluccas ring cowrie (MRC), a type of Cypraea annulus belonging to the Cypraeidae family, is small and categorized as a true cowrie [29-31]. Research on Cypraea annulus has practiced, in fact almost all its aspects have reported such as physical description [32,30,33], shell morphology [32,34,35], life history [36], genetic data [37,38] taxonomy [39], biomolecular systematics [38], reproduction [40,41], bioecology [42], sexuality $[43,44]$, distribution [45-47], patterns of growth and development $[48,49,26]$, approximate lifespan [50], phenotypic plasticity [35], phenetic relationship [51] and phenotypic classification [52]. Yet, of all the information, there are still limitations because the approach was qualitative and there was no information about quantitative aspects of trait, especially about phenotypic expression of morphometric (PEM), the morphometric taxa level (MTL) and the map of morphometric trait configuration (MTC). Though this information is very important and fundamental known to support the concept of sustainable and sustainable marine biota resource management. The MT information of an individual could explain the status and performance conditions can even standardize into individual trait performance indices in the species population $[8,26,52-54]$.

Knowledge and understanding of PEM, MTL, and MTC between subpopulations contributed to monitoring and evaluation of biota performance among subpopulations $[8,52,55]$, monitoring and evaluation of environmental and aquacultural systems, selection and hybridization programs in aquaculture [1,2,56-58], evaluating biota conditions and harvest planning even in determining the quality or selling price of aquaculture biota [59-61]. The activities of determining the performance and factors of the biota condition of aquaculture, monitoring and evaluation of aquaculture system, selection and hybridization programs had done, but there were still problems i.e expensive, difficult, subjective, qualitative, long time, and only a few traits $[59,20,62,63]$.

This study aimed to investigate phenotypic expression morphometric (PEM), to determine the morfometric taxa level (MTL) and to mapping of the morphometric trait configuration (MTC) between 32 subpopulations of the Moluccas ring cowrie (MRC), Cypraea annulus based on three types of morphometric trait (MT) data.

\section{Materials and Methods}

\section{Specimen Collection}

This study conducted for four years $(2013,2014,2015$ and 2016). MRC specimen collected from Moluccas waters from MTB Island and Ambon Island (Figure 1). Trait observations and measurements conducted at the Maritime and Marine Science Center for Excellence, Pattimura University; processing and data analysis 


\section{International Journal of Oceanography \& Aquaculture}

performed in Computational Biology Studios, Penabur Computech Ambon.

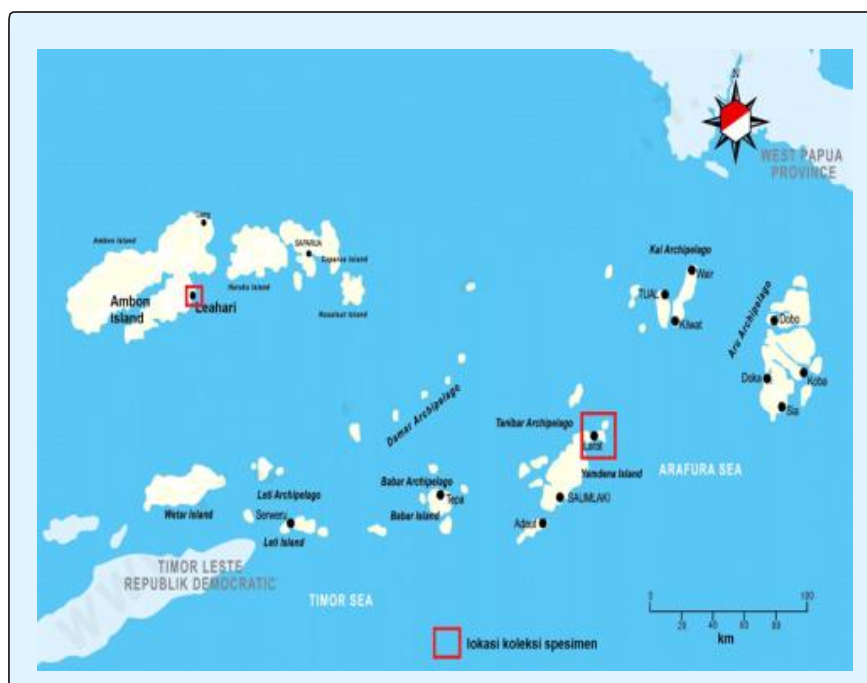

Figure 1: The location map of specimen collection of MRC (red square).
The MRC used 2926 specimens consist of 2160 from the MTB is land and 766 of the Ambon Island. Determination of subpopulations in this study was 32 subpopulations ( $\mathrm{t}$ ) originating from Cypraea annulus intra-species or sub-polarization based on geographical location (MTB and Ambon waters), seasons period of four seasons (2013, 2014, 2015 and 2016) and stages shell development (juvenile, subadult, adult and postadult). The geographic location of the specimens (Ambon Island and the waters of MTB) determined with the consideration that the number of samples is available in large quantities, available throughout the year, easy to get samples as well as long distances so about assume the distinct MRC population characteristic and not related to environment and lineage. Determination of developmental stage of the juvenile, subadult, adult and postadult, based on two approaches development stage of shell callus and morphological stage of the shell $[36,64,65]$. The determination of subpopulations in this study presented in Table 1. Label and code were given in 32 subpopulations to the analysis process with computer software.

\begin{tabular}{|c|l|c|c|}
\hline No. & \multicolumn{1}{|c|}{ Subpopulasi } & Label & Kode \\
\hline 1 & Juvenile on Ambon Island in 2013 & A3ju & 1 \\
\hline 2 & Subadult on Ambon Island in 2013 & A3sa & 2 \\
\hline 3 & Adult on Ambon Island in 2013 & A3ad & 3 \\
\hline 4 & Postadult on Ambon Island in 2013 & A3pa & 4 \\
\hline 5 & Juvenile on Ambon Island in 2014 & A4ju & 5 \\
\hline 6 & Subadult on Ambon Island in 2014 & A4sa & 6 \\
\hline 7 & Adult on Ambon Island in 2014 & A4ad & 7 \\
\hline 8 & Postadult on Ambon Island in 2014 & A4pa & 8 \\
\hline 9 & Juvenile on Ambon Island in 2015 & A5ju & 9 \\
\hline 10 & Subadult on Ambon Island in 2015 & A5sa & 10 \\
\hline 11 & Adult on Ambon Island in 2015 & A5ad & 11 \\
\hline 12 & Postadult on Ambon Island in 2015 & A5pa & 12 \\
\hline 13 & Juvenile on Ambon Island in 2016 & A6ju & 13 \\
\hline 14 & Subadult on Ambon Island in 2016 & A6sa & 14 \\
\hline 15 & Adult on Ambon Island in 2016 & A6ad & 15 \\
\hline 16 & Postadult on Ambon Island in 2016 & A6pa & 16 \\
\hline 17 & Juvenile on MTB Island in 2013 & M3ju & 17 \\
\hline 18 & Subadult on MTB Island in 2013 & M3sa & 18 \\
\hline 19 & Adult on MTB Island in 2013 & M3ad & 19 \\
\hline 20 & Postadult on MTB Island in 2013 & M3pa & 20 \\
\hline 21 & Juvenile on MTB Island in 2014 & M4ju & 21 \\
\hline 22 & Subadult on MTB Island in 2014 & M4sa & 22 \\
\hline 23 & Adult on MTB Island in 2014 & M4ad & 23 \\
\hline 24 & Postadult on MTB Island in 2014 & M4pa & 24 \\
\hline 25 & Juvenile on MTB Island in 2015 & M5ju & 25 \\
\hline 26 & Subadult on MTB Island in 2015 & M5sa & 26 \\
\hline & \multicolumn{2}{|l}{} \\
\hline
\end{tabular}




\section{International Journal of Oceanography \& Aquaculture}

\begin{tabular}{|l|l|c|c|}
\hline 27 & Adult on MTB Island in 2015 & M5ad & 27 \\
\hline 28 & Post adult on MTB Island in 2015 & M5pa & 28 \\
\hline 29 & Juvenile on MTB Island in 2016 & M6ju & 29 \\
\hline 30 & Subadult on MTB Island in 2016 & M6sa & 30 \\
\hline 31 & Adult on MTB Island in 2016 & M6ad & 31 \\
\hline 32 & Postadult on MTB Island in 2016 & M6pa & 32 \\
\hline
\end{tabular}

Table 1: Scheme of determination of 32 subpopulations of the MRC in this study.

\section{Data Collection}

The MT data retrieval based on the structure of the shell morphology with two approaches, macrometric, and micrometric. Macrometric trait measurements performed using a digital scale with a precision of $0.01 \mathrm{~g}$ to measure shell weight, whereas a $0.01 \mathrm{~mm}$ precision digital caliper used to measure shell length, shell width, and shell height with reference to the illustration as shown in figure 2 . The length of the shell measured from the anterior edge to the posterior end of the shell; the width of the shell measured from side to side on the widest whorl body, and the height of the shell measured from the basal or ventral to the widest dorsal end.

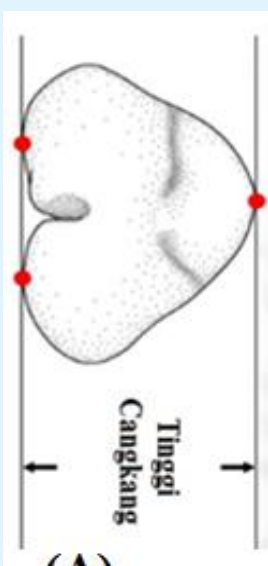

(A)

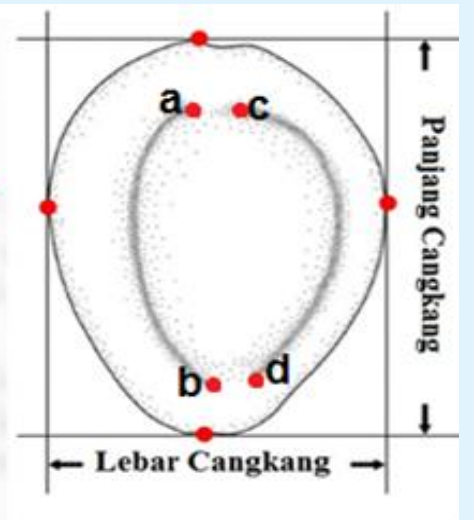

(B)
Figure 2: Illustration of morphometric measurement (macrometry) of MRC. A. Shell height; B. Shell Length, Shell Width, the perimeter of the right ring (a-b) and perimeter of the left ring (c-d).

Image capture used a digital camera with the Arsoft Companion software version 4.0.0.374 with 1280 x 960 pixels resolution. Image editing and processing using Adobe Photoshop CS3 and Adobe Illustrator CS3 into a scalar bitmap, while to make vector bitmap used CorelDraw X4. Furthermore, the image digitized using TPSDiq2 and TPSU tils32 software for analysis of the image.
Micrometric measurements performed through imprinted image data using the Image J 1.51i. Micrometric that measured aperture length, anterior channel width, posterior channel width, inner limb width, outer lip width, aperture width, anterior channel height, posterior channel height, anterior channel area, posterior channel area, shell surface area, the right ring, the perimeter of the left ring, the perimeter of the anterior channel, the perimeter of the posterior channel, and the perimeter of the surface of the shell. Illustration micrometric measurement refers to the illustration in Figure 3. The macrometric and micrometric data, then calculated the ratio between the traits to get 104 test traits for the three data types (Tables 2-4).

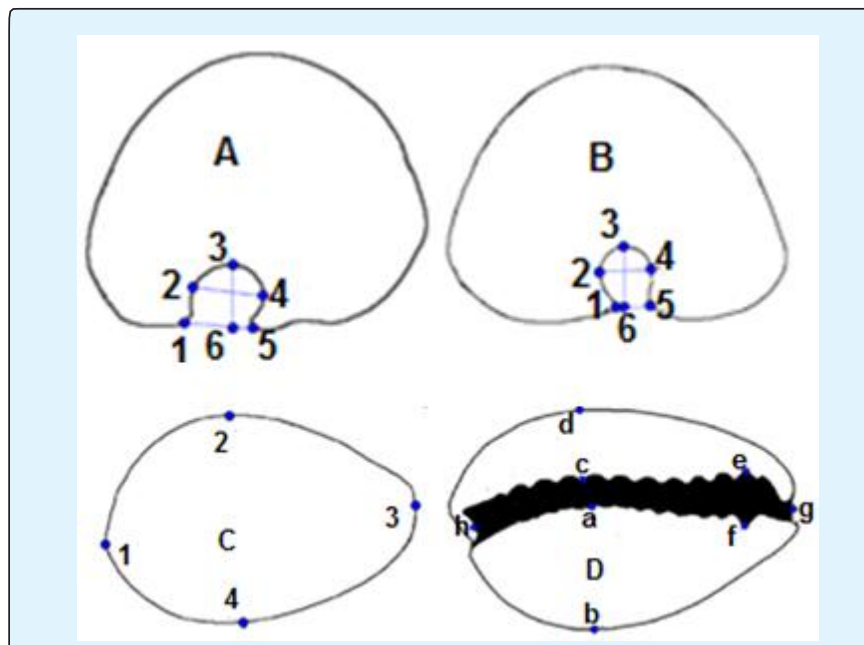

Figure 3: Illustration of morphometric measurement (micrometry) of MRC. A. Anterior channel: channel width (2-4), channel height (3-6), channel perimeter (1-2-3-4-5), and area channel (1-2-3-4-5-6 -1-). B. Posterior channel: channel width (2-4), channel height (3-6), channel perimeter (1-2-3-4-5), and channel area (1-2-3-4-5-6 -1-). C. the dorsal (outline of the dorsal side) scheme: the area and perimeter of the shell's surface (1-2-3-4-1). D. the outline of basal side scheme: the width of the inner lip (a-b), the width of the outer lip (c-d), the aperture width (e-f), and the aperture length (g-h). 


\section{International Journal of Oceanography \& Aquaculture}

\begin{tabular}{|c|c|c|}
\hline Num. & Character description & $\begin{array}{c}\text { Character states } \\
\text { (numeric) }\end{array}$ \\
\hline & The ratio of shell weight & \\
\hline 1 & The ratio of weight and the length of the shell & ........ \\
\hline 2 & The ratio of weight and the width of the shell & …...... \\
\hline 3 & The ratio of weight and the height of the shell & ........ \\
\hline 4 & The ratio of weight and length plus the width of the shell & $\ldots \ldots$. \\
\hline 5 & The ratio of weight and length plus the height of the shell & .......... \\
\hline 6 & The ratio of weight and width plus the height of the shell & .......... \\
\hline 7 & The ratio of weight and length plus width plus height of the shell & ......... \\
\hline 8 & The ratio of weight and length multiplied by the width of the shell & ......... \\
\hline 9 & The ratio of weight and length multiplied by the height of the shell & .......... \\
\hline 10 & The ratio of weight and width multiplied by the height of the shell & ......... \\
\hline \multirow[t]{2}{*}{11} & The ratio of weight and length multiplied by the width of the height of the shell & ......... \\
\hline & The ratio of shell Length ratio & \\
\hline 12 & The ratio of the length and weight of the shell & ........ \\
\hline 13 & The ratio of the length and width of the shell & ........ \\
\hline 14 & The ratio of the length and height of the shell & ......... \\
\hline 15 & The ratio of length and length plus shell width & ........ \\
\hline 16 & The ratio of length and length plus height of the shell & ........ \\
\hline 17 & The ratio of length and width plus the height of the shell & ........ \\
\hline 18 & The ratio of length and length plus width plus height of the shell & ......... \\
\hline 19 & The ratio of length and length multiplied by the width of the shell & ......... \\
\hline 20 & The ratio of length and length multiplied by the height of the shell & ......... \\
\hline 21 & The ratio of length and width multiplied by the height of the shell & ......... \\
\hline \multirow[t]{2}{*}{22} & The ratio of length and length times the width of the height of the shell & …...... \\
\hline & The ratio of shell width & \\
\hline 23 & The ratio of the width and weight of the shell & ........ \\
\hline 24 & The ratio of the width and length of the shell & ......... \\
\hline 25 & The ratio of the width and height of the shell & $\ldots \ldots$. \\
\hline 26 & The ratio of width and length plus width of the shell & .......... \\
\hline 27 & The ratio of width and length plus the height of the shell & …..... \\
\hline 28 & The ratio of width and width plus shell height & ........ \\
\hline 29 & The ratio of width and length plus width plus height of the shell & …...... \\
\hline 30 & The ratio of width and length multiplied by the width of the shell & ......... \\
\hline 31 & The ratio of width and length times the height of the shell & ......... \\
\hline 32 & The ratio of width and width multiplied by the height of the shell & ......... \\
\hline \multirow[t]{2}{*}{33} & The ratio of width and length times the width of the height of the shell & ......... \\
\hline & The ratio of shell Height & \\
\hline 34 & The ratio of height and weight of the shell & $\ldots \ldots$. \\
\hline 35 & The ratio of height and length of the shell & ......... \\
\hline 36 & The ratio of height and width of the shell & ........ \\
\hline 37 & The ratio of height and length plus width of the shell & ......... \\
\hline 38 & The ratio of height and length plus the height of the shell & …...... \\
\hline 39 & The ratio of height and width plus the height of the shell & …...... \\
\hline 40 & The ratio of height and length plus width plus height of the shell & ........ \\
\hline 41 & The ratio of height and length multiplied by the width of the shell & ........ \\
\hline 42 & The ratio of height and length multiplied by the height of the shell & ......... \\
\hline 43 & The ratio of height and width multiplied by the height of the shell & ......... \\
\hline 44 & The ratio of height and length times the width of the height of the shell & ......... \\
\hline
\end{tabular}




\section{International Journal of Oceanography \& Aquaculture}

\begin{tabular}{|c|c|c|}
\hline & The ratio of shell channel & \\
\hline 45 & The ratio of height and width of the anterior channel & $\ldots \ldots$. \\
\hline 46 & The ratio of area and perimeter of the anterior channel & ........ \\
\hline 47 & The ratio of height and width of the posterior channel & ......... \\
\hline 48 & The ratio of area and perimeter of the anterior channel & ........ \\
\hline 49 & The ratio of height of the anterior and posterior channel & $\ldots \ldots .$. \\
\hline 50 & The ratio of width of the anterior and posterior channel & ......... \\
\hline 51 & The ratio of area of the anterior and posterior channel & ........ \\
\hline 52 & The ratio of perimeter of the anterior and posterior channel & ........ \\
\hline 53 & The ratio of height of the anterior channel and height of the shell & ........ \\
\hline 54 & The ratio of width of the anterior channel and width of the shell & $\ldots \ldots$. \\
\hline 55 & The ratio of perimeter of the anterior channel and length of the shell & $\ldots \ldots$. \\
\hline 56 & The ratio of perimeter of the anterior channel and perimeter of the shell & $\ldots \ldots$. \\
\hline 57 & The ratio of area of the anterior channel and area of the shell & $\ldots \ldots$. \\
\hline 58 & The ratio of height of the posterior channel and height of the shell & $\ldots \ldots$. \\
\hline 59 & The ratio of width of the posterior channel and width of the shell & $\ldots \ldots .$. \\
\hline 60 & The ratio of perimeter of the posterior channel and length of the shell & $\ldots \ldots . .$. \\
\hline 61 & The ratio of perimeter of the posterior channel and perimeter of the shell & $\ldots . . .$. \\
\hline 62 & The ratio of area of the posterior channel and area of the shell & ....... \\
\hline 63 & The ratio of height of the anterior channel and width of the shell & ........ \\
\hline 64 & The ratio of width of the anterior channel and length of the shell & ........ \\
\hline 65 & The ratio of width of the anterior channel and width of the aperture & ........ \\
\hline 66 & The ratio of height of the anterior channel and width of the aperture & $\ldots . . .$. \\
\hline 67 & The ratio of height of the posterior channel and width of the shell & $\ldots \ldots$. \\
\hline 68 & The ratio of width of the posterior channel and length of the shell & $\ldots \ldots$. \\
\hline 69 & The ratio of width of the posterior channel and width of the aperture & ........ \\
\hline \multirow[t]{2}{*}{70} & The ratio of height of the posterior channel and width of the aperture & ........ \\
\hline & The ratio of shell aperture & \\
\hline 71 & The ratio of width and length of the aperture & $\ldots \ldots$. \\
\hline 72 & The ratio of width of the aperture and width inner lip & ........ \\
\hline 73 & The ratio of width of the aperture and width outer lip & ........ \\
\hline 74 & The ratio of width of the aperture and width of the shell & ........ \\
\hline 75 & The ratio of length of the aperture and length of the shell & $\ldots \ldots$. \\
\hline 76 & The ratio of width of the aperture and area of the shell & ........ \\
\hline 77 & The ratio of length of the aperture and area of the shell & $\ldots \ldots$. \\
\hline 78 & The ratio of length of the aperture and perimeter of the shell & $\ldots \ldots$. \\
\hline 79 & The ratio of width of the aperture and perimeter of the shell & $\ldots \ldots .$. \\
\hline 80 & The ratio of width of the aperture and height of the shell & $\ldots . . .$. \\
\hline 81 & The ratio of length of the aperture and height of the shell & ........ \\
\hline \multirow[t]{2}{*}{82} & The ratio of length of the aperture and width of the shell & $\ldots \ldots$. \\
\hline & The ratio of shell lips & \\
\hline 83 & The ratio of width of the inner and outer lips & $\ldots \ldots$. \\
\hline 84 & The ratio of width of the inner lip and width of the shell & ........ \\
\hline 85 & The ratio of width of the inner lip and height of the shell & $\ldots . . .$. \\
\hline 86 & The ratio of width of the inner lip and length of the shell & $\ldots \ldots$. \\
\hline 87 & The ratio of width of the inner lip and perimeter of the shell & ........ \\
\hline 88 & The ratio of width of the inner lip and area of the shell & ........ \\
\hline 89 & The ratio of width of the outer lip and width of the shell & $\ldots \ldots$. \\
\hline 90 & The ratio of width of the outer lip and height of the shell & ........ \\
\hline 91 & The ratio of width of the outer lip and length of the shell & ........ \\
\hline
\end{tabular}




\begin{tabular}{|c|l|c|}
\hline 92 & The ratio of width of the outer lip and perimeter of the shell & $\ldots \ldots$ \\
\hline 93 & The ratio of width of the outer lip and area of the shell & $\ldots \ldots$. \\
\hline 94 & The ratio of width of the inner lip and length of the aperture & $\ldots \ldots$. \\
\hline 95 & The ratio of width of the outer lip and length of the aperture & $\ldots \ldots$. \\
\hline & The ratio shell surface (dorsal outline) & $\ldots \ldots$ \\
\hline 96 & The ratio of perimeter and area of the shell surface & $\ldots \ldots$. \\
\hline 98 & The ratio of length and perimeter of the shell & $\ldots \ldots$ \\
\hline 99 & The ratio of length and area of the shell surface & $\ldots \ldots$. \\
\hline 100 & The ratio of weight and perimeter of the shell & $\ldots \ldots$. \\
\hline 101 & The ratio of width and perimeter of the shell surface & $\ldots \ldots$. \\
\hline 103 & The ratio of width and area of the shell surface & $\ldots \ldots$. \\
\hline 104 & The ratio of height and perimeter of the shell surface & $\ldots \ldots$. \\
\hline
\end{tabular}

Table 2: The test characters of MRC, Cypraea annulus and its state based on morphometric traits for numerical data type.

\begin{tabular}{|c|c|c|c|c|c|c|}
\hline \multirow{2}{*}{ Num. } & \multirow{2}{*}{ Character description } & \multicolumn{5}{|c|}{ Character states (ordinary) } \\
\hline & & 1 & 2 & 3 & 4 & 5 \\
\hline & The ratio of shell weight & & & & & \\
\hline 1 & The ratio of weight and length of the shell & $\begin{array}{c}\text { less than } \\
1.05 \%\end{array}$ & $\begin{array}{l}1.05 \% \text { to } \\
7.96 \%\end{array}$ & $\begin{array}{l}7.97 \% \text { to } \\
12.82 \%\end{array}$ & $\begin{array}{c}\text { more than } \\
12.82 \%\end{array}$ & $\begin{array}{l}\text { Absent or } \\
\text { NM }\end{array}$ \\
\hline 2 & The ratio of weight and width of the shell & $\begin{array}{l}\text { less than } \\
1.59 \%\end{array}$ & $\begin{array}{l}1.59 \% \text { to } \\
12.58 \%\end{array}$ & $\begin{array}{l}12.59 \% \text { to } \\
17.27 \%\end{array}$ & $\begin{array}{l}\text { more than } \\
17.27 \%\end{array}$ & $\begin{array}{l}\text { Absent or } \\
\text { NM }\end{array}$ \\
\hline 3 & The ratio of weight and height of the shell & $\begin{array}{l}\text { less than } \\
2.10 \%\end{array}$ & $\begin{array}{l}2.10 \% \text { to } \\
17.08 \%\end{array}$ & $\begin{array}{l}17.09 \% \text { to } \\
23.84 \%\end{array}$ & $\begin{array}{l}\text { more than } \\
23.84 \%\end{array}$ & $\begin{array}{l}\text { Absent or } \\
\text { NM }\end{array}$ \\
\hline 4 & $\begin{array}{l}\text { The ratio of weight and length plus the width } \\
\text { of the shell }\end{array}$ & $\begin{array}{l}\text { less than } \\
0.63 \%\end{array}$ & $\begin{array}{l}0.63 \% \text { to } \\
4.88 \%\end{array}$ & $\begin{array}{l}4.89 \% \text { to } \\
7.32 \%\end{array}$ & $\begin{array}{l}\text { more than } \\
7.32 \%\end{array}$ & $\begin{array}{l}\text { Absent or } \\
\text { NM }\end{array}$ \\
\hline 5 & $\begin{array}{l}\text { The ratio of weight and length plus the height } \\
\text { of the shell }\end{array}$ & $\begin{array}{l}\text { less than } \\
0.70 \%\end{array}$ & $\begin{array}{l}0.70 \% \text { to } \\
5.43 \%\end{array}$ & $\begin{array}{l}5.44 \% \text { to } \\
8.25 \%\end{array}$ & $\begin{array}{l}\text { more than } \\
8.25 \%\end{array}$ & $\begin{array}{c}\text { Absent or } \\
\text { NM }\end{array}$ \\
\hline 6 & $\begin{array}{l}\text { The ratio of weight and width plus the height } \\
\text { of the shell }\end{array}$ & $\begin{array}{l}\text { less than } \\
0.90 \%\end{array}$ & $\begin{array}{l}0.90 \% \text { to } \\
7.25 \%\end{array}$ & $\begin{array}{l}7.26 \% \text { to } \\
9.93 \%\end{array}$ & $\begin{array}{l}\text { more than } \\
9.93 \%\end{array}$ & $\begin{array}{c}\text { Absent or } \\
\text { NM }\end{array}$ \\
\hline 7 & $\begin{array}{l}\text { The ratio of weight and length plus width plus } \\
\text { height of the shell }\end{array}$ & $\begin{array}{c}\text { less than } \\
0.49 \%\end{array}$ & $\begin{array}{l}0.49 \% \text { to } \\
3.79 \%\end{array}$ & $\begin{array}{l}3.80 \% \text { to } \\
5.56 \%\end{array}$ & $\begin{array}{l}\text { more than } \\
5.56 \%\end{array}$ & $\begin{array}{l}\text { Absent or } \\
\text { NM }\end{array}$ \\
\hline 8 & $\begin{array}{l}\text { The ratio of weight and length multiplied by } \\
\text { the width of the shell }\end{array}$ & $\begin{array}{c}\text { less than } \\
0.11 \%\end{array}$ & $\begin{array}{l}0.11 \% \text { to } \\
0.54 \%\end{array}$ & $\begin{array}{l}0.55 \% \text { to } \\
0.83 \%\end{array}$ & $\begin{array}{c}\text { more than } \\
0.83 \%\end{array}$ & $\begin{array}{l}\text { Absent or } \\
\text { NM }\end{array}$ \\
\hline 9 & $\begin{array}{l}\text { The ratio of weight and length multiplied by } \\
\text { the height of the shell }\end{array}$ & $\begin{array}{c}\text { less than } \\
0.16 \%\end{array}$ & $\begin{array}{c}0.16 \% \text { to } \\
0.73 \%\end{array}$ & $\begin{array}{c}0.74 \% \text { to } \\
1.12 \%\end{array}$ & $\begin{array}{c}\text { more than } \\
1.12 \%\end{array}$ & $\begin{array}{c}\text { Absent or } \\
\text { NM }\end{array}$ \\
\hline 10 & $\begin{array}{l}\text { The ratio of weight and width multiplied by } \\
\text { the height of the shell }\end{array}$ & $\begin{array}{c}\text { less than } \\
0.25 \%\end{array}$ & $\begin{array}{c}0.25 \% \text { to } \\
1.16 \%\end{array}$ & $\begin{array}{l}1.17 \% \text { to } \\
1.82 \%\end{array}$ & $\begin{array}{c}\text { more than } \\
1.82 \%\end{array}$ & $\begin{array}{l}\text { Absent or } \\
\text { NM }\end{array}$ \\
\hline \multirow[t]{2}{*}{11} & $\begin{array}{l}\text { The ratio of weight and length multiplied by } \\
\text { the width of the height of the shell }\end{array}$ & $\begin{array}{c}\text { less than } \\
0.01 \% \\
\end{array}$ & $\begin{array}{c}0.01 \% \text { to } \\
0.05 \%\end{array}$ & $\begin{array}{c}0.06 \% \text { to } \\
0.11 \%\end{array}$ & $\begin{array}{c}\text { more than } \\
0.11 \%\end{array}$ & $\begin{array}{c}\text { Absent or } \\
\text { NM }\end{array}$ \\
\hline & The ratio of shell length & & & & & \\
\hline 12 & The ratio of the length and weight of the shell & $\begin{array}{l}\text { less than } \\
779.99 \%\end{array}$ & $\begin{array}{c}779.99 \% \text { to } \\
1255.91 \%\end{array}$ & $\begin{array}{c}1255.92 \% \text { to } \\
9529.90 \%\end{array}$ & $\begin{array}{l}\text { more than } \\
9529.90 \%\end{array}$ & $\begin{array}{c}\text { Absent or } \\
\text { NM }\end{array}$ \\
\hline 13 & The ratio of the length and width of the shell & $\begin{array}{l}\text { less than } \\
128.35 \%\end{array}$ & $\begin{array}{c}128.35 \% \text { to } \\
158.05 \%\end{array}$ & \begin{tabular}{|c|}
$158.06 \%$ to \\
$216.23 \%$
\end{tabular} & $\begin{array}{c}\text { more than } \\
216.23 \%\end{array}$ & $\begin{array}{l}\text { Absent or } \\
\text { NM }\end{array}$ \\
\hline 14 & The ratio of the length and height of the shell & $\begin{array}{l}\text { less than } \\
172.19 \%\end{array}$ & $\begin{array}{c}172.19 \% \text { to } \\
214.51 \%\end{array}$ & \begin{tabular}{|c|}
$214.52 \%$ to \\
$312.34 \%$
\end{tabular} & $\begin{array}{c}\text { more than } \\
312.34 \%\end{array}$ & $\begin{array}{c}\text { Absent or } \\
\text { NM }\end{array}$ \\
\hline
\end{tabular}




\section{International Journal of Oceanography \& Aquaculture}

\begin{tabular}{|c|c|c|c|c|c|c|}
\hline 15 & The ratio of length and length plus shell width & $\begin{array}{l}\text { less than } \\
56.21 \%\end{array}$ & $\begin{array}{c}56.21 \% \text { to } \\
61.25 \% \\
\end{array}$ & $\begin{array}{c}61.26 \% \text { to } \\
68.38 \% \\
\end{array}$ & $\begin{array}{c}\text { more than } \\
68.38 \% \\
\end{array}$ & \begin{tabular}{|c|} 
Absent or \\
NM
\end{tabular} \\
\hline 16 & $\begin{array}{l}\text { The ratio of length and length plus height of } \\
\text { the shell }\end{array}$ & $\begin{array}{c}\text { less than } \\
63.26 \%\end{array}$ & $\begin{array}{l}63.26 \% \text { to } \\
68.20 \%\end{array}$ & $\begin{array}{c}68.21 \% \text { to } \\
75.75 \%\end{array}$ & $\begin{array}{c}\text { more than } \\
75.75 \%\end{array}$ & $\begin{array}{c}\text { Absent or } \\
\text { NM }\end{array}$ \\
\hline 17 & $\begin{array}{l}\text { The ratio of length and width plus the height of } \\
\text { the shell }\end{array}$ & $\begin{array}{l}\text { less than } \\
75.46 \%\end{array}$ & $\begin{array}{l}75.46 \% \text { to } \\
91.00 \%\end{array}$ & $\begin{array}{c}91.01 \% \text { to } \\
116.52 \%\end{array}$ & $\begin{array}{c}\text { more than } \\
116.52 \%\end{array}$ & \begin{tabular}{|c|} 
Absent or \\
NM
\end{tabular} \\
\hline 18 & $\begin{array}{l}\text { The ratio of length and length plus width plus } \\
\text { height of the shell }\end{array}$ & $\begin{array}{l}\text { less than } \\
43.01 \%\end{array}$ & $\begin{array}{l}43.01 \% \text { to } \\
47.64 \%\end{array}$ & $\begin{array}{c}47.65 \% \text { to } \\
53.82 \%\end{array}$ & $\begin{array}{c}\text { more than } \\
53.82 \%\end{array}$ & $\begin{array}{c}\text { Absent or } \\
\text { NM }\end{array}$ \\
\hline 19 & $\begin{array}{l}\text { The ratio of length and length multiplied by } \\
\text { the width of the shell }\end{array}$ & $\begin{array}{l}\text { less than } \\
5.76 \%\end{array}$ & $\begin{array}{c}5.76 \% \text { to } \\
6.77 \% \\
\end{array}$ & $\begin{array}{c}6.78 \% \text { to } \\
13.52 \% \\
\end{array}$ & $\begin{array}{c}\text { more than } \\
13.52 \% \\
\end{array}$ & \begin{tabular}{|c|} 
Absent or \\
NM
\end{tabular} \\
\hline 20 & $\begin{array}{l}\text { The ratio of length and length multiplied by } \\
\text { the height of the shell }\end{array}$ & $\begin{array}{c}\text { less than } \\
7.45 \%\end{array}$ & $\begin{array}{l}7.45 \% \text { to } \\
12.92 \% \\
\end{array}$ & $\begin{array}{c}12.93 \% \text { to } \\
17.33 \% \\
\end{array}$ & $\begin{array}{c}\text { more than } \\
17.33 \% \\
\end{array}$ & \begin{tabular}{|c|} 
Absent or \\
NM
\end{tabular} \\
\hline 21 & $\begin{array}{l}\text { The ratio of length and width multiplied by the } \\
\text { height of the shell }\end{array}$ & $\begin{array}{c}\text { less than } \\
11.09 \% \\
\end{array}$ & $\begin{array}{c}11.09 \% \text { to } \\
14.51 \%\end{array}$ & $\begin{array}{c}14.52 \% \text { to } \\
30.56 \% \\
\end{array}$ & $\begin{array}{c}\text { more than } \\
30.56 \% \\
\end{array}$ & \begin{tabular}{|c|} 
Absent or \\
NM
\end{tabular} \\
\hline \multirow[t]{2}{*}{22} & $\begin{array}{l}\text { The ratio of length and length times the width } \\
\text { of the height of the shell }\end{array}$ & $\begin{array}{c}\text { less than } \\
0.44 \% \\
\end{array}$ & $\begin{array}{c}0.44 \% \text { to } \\
0.62 \% \\
\end{array}$ & $\begin{array}{c}0.63 \% \text { to } \\
2.34 \% \\
\end{array}$ & $\begin{array}{c}\text { more than } \\
2.34 \% \\
\end{array}$ & \begin{tabular}{|c|}
$\begin{array}{c}\text { Absent or } \\
\text { NM }\end{array}$ \\
\end{tabular} \\
\hline & tio of shell width & & & & & \\
\hline 23 & The ratio of the width and weight of the shell & $\begin{array}{l}\text { less than } \\
578.97 \%\end{array}$ & $\begin{array}{l}578.97 \% \text { to } \\
794.62 \%\end{array}$ & $\begin{array}{l}794.63 \% \text { to } \\
6299.28 \%\end{array}$ & $\begin{array}{l}\text { more than } \\
6299.28 \%\end{array}$ & $\begin{array}{c}\text { Absent or } \\
\text { NM }\end{array}$ \\
\hline 24 & The ratio of the width and length of the shell & $\begin{array}{l}\text { less than } \\
46.25 \%\end{array}$ & $\begin{array}{l}46.25 \% \text { to } \\
63.27 \%\end{array}$ & $\begin{array}{l}63.28 \% \text { to } \\
77.91 \%\end{array}$ & $\begin{array}{c}\text { more than } \\
77.91 \% \\
\end{array}$ & \begin{tabular}{|c|} 
Absent or \\
NM
\end{tabular} \\
\hline 25 & The ratio of width and height of the shell & $\begin{array}{l}\text { less than } \\
98.86 \%\end{array}$ & $\begin{array}{l}98.86 \% \text { to } \\
135.72 \% \\
\end{array}$ & $\begin{array}{c}135.73 \% \text { to } \\
192.64 \%\end{array}$ & $\begin{array}{c}\text { more than } \\
192.64 \% \\
\end{array}$ & \begin{tabular}{|c|}
$\begin{array}{c}\text { Absent or } \\
\text { NM }\end{array}$ \\
\end{tabular} \\
\hline 26 & $\begin{array}{l}\text { The ratio of width and length plus width of the } \\
\text { shell }\end{array}$ & $\begin{array}{c}\text { less than } \\
31.62 \%\end{array}$ & $\begin{array}{l}31.62 \% \text { to } \\
38.75 \%\end{array}$ & $\begin{array}{c}38.76 \% \text { to } \\
43.79 \%\end{array}$ & $\begin{array}{c}\text { more than } \\
43.79 \%\end{array}$ & $\begin{array}{c}\text { Absent or } \\
\text { NM }\end{array}$ \\
\hline 27 & $\begin{array}{l}\text { The ratio of width and length plus the height of } \\
\text { the shell }\end{array}$ & $\begin{array}{l}\text { less than } \\
31.80 \%\end{array}$ & $\begin{array}{l}31.80 \% \text { to } \\
43.15 \%\end{array}$ & $\begin{array}{l}43.16 \% \text { to } \\
51.36 \%\end{array}$ & $\begin{array}{c}\text { more than } \\
51.36 \%\end{array}$ & \begin{tabular}{|c|} 
Absent or \\
NM
\end{tabular} \\
\hline 28 & $\begin{array}{l}\text { The ratio of width and width plus height of the } \\
\text { shell }\end{array}$ & $\begin{array}{c}\text { less than } \\
49.71 \%\end{array}$ & $\begin{array}{l}49.71 \% \text { to } \\
57.58 \%\end{array}$ & $\begin{array}{c}57.59 \% \text { to } \\
65.83 \%\end{array}$ & $\begin{array}{c}\text { more than } \\
65.83 \% \\
\end{array}$ & \begin{tabular}{|c|} 
Absent or \\
NM
\end{tabular} \\
\hline 29 & $\begin{array}{l}\text { The ratio of width and length plus width plus } \\
\text { height of the shell }\end{array}$ & $\begin{array}{l}\text { less than } \\
24.13 \%\end{array}$ & $\begin{array}{l}24.13 \% \text { to } \\
30.14 \%\end{array}$ & $\begin{array}{c}30.15 \% \text { to } \\
33.93 \%\end{array}$ & $\begin{array}{c}\text { more than } \\
33.93 \%\end{array}$ & $\begin{array}{c}\text { Absent or } \\
\text { NM }\end{array}$ \\
\hline 30 & $\begin{array}{l}\text { The ratio of width and length multiplied by the } \\
\text { width of the shell }\end{array}$ & $\begin{array}{l}\text { less than } \\
3.79 \%\end{array}$ & $\begin{array}{c}3.79 \% \text { to } \\
4.28 \%\end{array}$ & $\begin{array}{l}4.29 \% \text { to } \\
8.99 \%\end{array}$ & $\begin{array}{c}\text { more than } \\
8.99 \%\end{array}$ & $\begin{array}{c}\text { Absent or } \\
\text { NM }\end{array}$ \\
\hline 31 & $\begin{array}{l}\text { The ratio of width and length times the height } \\
\text { of the shell }\end{array}$ & $\begin{array}{l}\text { less than } \\
4.79 \%\end{array}$ & $\begin{array}{l}4.79 \% \text { to } \\
5.81 \%\end{array}$ & $\begin{array}{l}5.82 \% \text { to } \\
12.17 \%\end{array}$ & $\begin{array}{c}\text { more than } \\
12.17 \%\end{array}$ & $\begin{array}{c}\text { Absent or } \\
\text { NM }\end{array}$ \\
\hline 32 & $\begin{array}{l}\text { The ratio of width and width multiplied by the } \\
\text { height of the shell }\end{array}$ & $\begin{array}{l}\text { less than } \\
7.45 \%\end{array}$ & $\begin{array}{l}7.45 \% \text { to } \\
9.18 \%\end{array}$ & $\begin{array}{l}9.19 \% \text { to } \\
17.33 \%\end{array}$ & $\begin{array}{c}\text { more than } \\
17.33 \%\end{array}$ & $\begin{array}{c}\text { Absent or } \\
\text { NM }\end{array}$ \\
\hline \multirow[t]{2}{*}{33} & $\begin{array}{l}\text { The ratio of width and length times the width } \\
\text { of the height of the shell }\end{array}$ & $\begin{array}{c}\text { less than } \\
0.29 \% \\
\end{array}$ & $\begin{array}{c}0.29 \% \text { to } \\
0.39 \% \\
\end{array}$ & $\begin{array}{c}0.40 \% \text { to } \\
1.49 \% \\
\end{array}$ & $\begin{array}{c}\text { more than } \\
1.49 \% \\
\end{array}$ & \begin{tabular}{|c|} 
Absent or \\
NM
\end{tabular} \\
\hline & The ratio of shell height & & & & & \\
\hline 34 & The ratio of height and weight of the shell & $\begin{array}{l}\text { less than } \\
419.49 \%\end{array}$ & $\begin{array}{l}419.49 \% \text { to } \\
585.48 \%\end{array}$ & $\begin{array}{c}585.49 \% \text { to } \\
4756.40 \%\end{array}$ & $\begin{array}{l}\text { more than } \\
4756.40 \%\end{array}$ & \begin{tabular}{|c|} 
absent or \\
NM
\end{tabular} \\
\hline 35 & The ratio of height and length of the shell & $\begin{array}{l}\text { less than } \\
32.02 \%\end{array}$ & $\begin{array}{l}32.02 \% \text { to } \\
46.62 \%\end{array}$ & $\begin{array}{l}46.63 \% \text { to } \\
58.07 \%\end{array}$ & $\begin{array}{c}\text { more than } \\
58.07 \% \\
\end{array}$ & \begin{tabular}{|c|} 
Absent or \\
NM
\end{tabular} \\
\hline 36 & The ratio of height and width of the shell & $\begin{array}{l}\text { less than } \\
51.91 \% \\
\end{array}$ & $\begin{array}{l}51.91 \% \text { to } \\
73.68 \%\end{array}$ & $\begin{array}{c}73.69 \% \text { to } \\
101.15 \% \\
\end{array}$ & $\begin{array}{c}\text { more than } \\
101.15 \% \\
\end{array}$ & \begin{tabular}{|c|} 
Absent or \\
NM
\end{tabular} \\
\hline 37 & $\begin{array}{l}\text { The ratio of height and length plus the width of } \\
\text { the shell }\end{array}$ & $\begin{array}{c}\text { less than } \\
19.80 \%\end{array}$ & $\begin{array}{c}19.80 \% \text { to } \\
28.55 \%\end{array}$ & $\begin{array}{c}28.56 \% \text { to } \\
34.92 \%\end{array}$ & $\begin{array}{c}\text { more than } \\
34.92 \%\end{array}$ & $\begin{array}{c}\text { Absent or } \\
\text { NM }\end{array}$ \\
\hline 38 & The ratio of height and length plus the height & less than & $24.25 \%$ to & $31.81 \%$ to & more than & Absent or \\
\hline
\end{tabular}




\section{International Journal of Oceanography \& Aquaculture}

\begin{tabular}{|c|c|c|c|c|c|c|}
\hline & of the shell & $24.25 \%$ & $31.80 \%$ & $36.74 \%$ & $36.74 \%$ & NM \\
\hline 39 & $\begin{array}{l}\text { The ratio of height and width plus the height of } \\
\text { the shell }\end{array}$ & $\begin{array}{l}\text { less than } \\
34.17 \%\end{array}$ & $\begin{array}{c}34.17 \% \text { to } \\
42.42 \%\end{array}$ & $\begin{array}{l}42.43 \% \text { to } \\
50.29 \%\end{array}$ & $\begin{array}{c}\text { more than } \\
50.29 \%\end{array}$ & $\begin{array}{c}\text { Absent or } \\
\text { NM }\end{array}$ \\
\hline 40 & $\begin{array}{l}\text { The ratio of height and length plus width plus } \\
\text { height of the shell }\end{array}$ & $\begin{array}{l}\text { less than } \\
16.53 \%\end{array}$ & $\begin{array}{c}16.53 \% \text { to } \\
22.21 \%\end{array}$ & $\begin{array}{l}22.22 \% \text { to } \\
25.88 \%\end{array}$ & $\begin{array}{c}\text { more than } \\
25.88 \%\end{array}$ & $\begin{array}{c}\text { Absent or } \\
\text { NM }\end{array}$ \\
\hline 41 & $\begin{array}{l}\text { The ratio of height and length multiplied by } \\
\text { the width of the shell }\end{array}$ & \begin{tabular}{|c|} 
less \\
than $2.71 \%$ \\
\end{tabular} & $\begin{array}{c}2.71 \% \text { to } \\
3.15 \%\end{array}$ & $\begin{array}{l}3.16 \% \text { to } \\
7.47 \%\end{array}$ & $\begin{array}{c}\text { more than } \\
7.47 \%\end{array}$ & $\begin{array}{c}\text { Absent or } \\
\text { NM }\end{array}$ \\
\hline 42 & $\begin{array}{l}\text { The ratio of height and length multiplied by } \\
\text { the height of the shell }\end{array}$ & $\begin{array}{l}\text { less than } \\
3.79 \%\end{array}$ & $\begin{array}{l}3.79 \% \text { to } \\
4.28 \%\end{array}$ & $\begin{array}{l}4.29 \% \text { to } \\
8.99 \%\end{array}$ & $\begin{array}{c}\text { more than } \\
8.99 \%\end{array}$ & $\begin{array}{l}\text { Absent or } \\
\text { NM }\end{array}$ \\
\hline 43 & $\begin{array}{l}\text { The ratio of height and width multiplied by the } \\
\text { height of the shell }\end{array}$ & $\begin{array}{l}\text { less than } \\
5.76 \%\end{array}$ & $\begin{array}{l}5.76 \% \text { to } \\
6.77 \%\end{array}$ & $\begin{array}{l}6.78 \% \text { to } \\
13.52 \%\end{array}$ & $\begin{array}{c}\text { more than } \\
13.52 \%\end{array}$ & $\begin{array}{l}\text { Absent or } \\
\text { NM }\end{array}$ \\
\hline \multirow[t]{2}{*}{44} & $\begin{array}{l}\text { The ratio of height and length times the width } \\
\text { of the height of the shell }\end{array}$ & $\begin{array}{l}\text { less than } \\
0.22 \% \\
\end{array}$ & $\begin{array}{l}0.22 \% \text { to } \\
0.29 \%\end{array}$ & $\begin{array}{c}0.30 \% \text { to } \\
1.16 \% \\
\end{array}$ & $\begin{array}{c}\text { more than } \\
1.16 \% \\
\end{array}$ & $\begin{array}{c}\text { Absent or } \\
\text { NM }\end{array}$ \\
\hline & The ratio of shell channel & & & & & \\
\hline 45 & Dits & $\begin{array}{l}\text { less than } \\
2.27 \%\end{array}$ & $\begin{array}{l}2.27 \% \text { to } \\
97.19 \% \\
\end{array}$ & $\begin{array}{l}97.20 \% \text { to } \\
255.27 \% \\
\end{array}$ & $\begin{array}{c}\text { more than } \\
255.27 \% \\
\end{array}$ & $\begin{array}{c}\text { Absent or } \\
\text { NM }\end{array}$ \\
\hline 46 & $\begin{array}{l}\text { The ratio of area and perimeter of the anterior } \\
\text { channel }\end{array}$ & $\begin{array}{c}\text { less than } \\
3.27 \%\end{array}$ & $\begin{array}{l}3.27 \% \text { to } \\
66.03 \%\end{array}$ & $\begin{array}{l}66.04 \% \text { to } \\
820.13 \%\end{array}$ & $\begin{array}{l}\text { more than } \\
820.13 \% \\
\end{array}$ & $\begin{array}{c}\text { Absent or } \\
\text { NM }\end{array}$ \\
\hline 47 & $\begin{array}{l}\text { The ratio of height and width of the posterior } \\
\text { channel }\end{array}$ & $\begin{array}{l}\text { less than } \\
3.25 \% \\
\end{array}$ & $\begin{array}{l}3.25 \% \text { to } \\
98.85 \%\end{array}$ & $\begin{array}{l}98.86 \% \text { to } \\
293.98 \% \\
\end{array}$ & $\begin{array}{c}\text { more than } \\
293.98 \% \\
\end{array}$ & $\begin{array}{c}\text { Absent or } \\
\text { NM }\end{array}$ \\
\hline 48 & of area and perimeter of the anterior & $\begin{array}{c}\text { less than } \\
1.11 \%\end{array}$ & $\begin{array}{l}1.11 \% \text { to } \\
64.73 \%\end{array}$ & $\begin{array}{c}64.74 \% \text { to } \\
153.36 \%\end{array}$ & $\begin{array}{c}\text { more than } \\
153.36 \% \\
\end{array}$ & $\begin{array}{c}\text { Absent or } \\
\text { NM }\end{array}$ \\
\hline 49 & $\begin{array}{l}\text { of height of the anterior and } \\
\text { channel }\end{array}$ & $\begin{array}{c}\text { less than } \\
3.25 \% \\
\end{array}$ & $\begin{array}{l}3.25 \% \text { to } \\
96.15 \% \\
\end{array}$ & $\begin{array}{l}96.16 \% \text { to } \\
292.47 \%\end{array}$ & $\begin{array}{c}\text { more than } \\
292.47 \% \\
\end{array}$ & $\begin{array}{c}\text { Absent or } \\
\text { NM }\end{array}$ \\
\hline 50 & of the anterior and & $\begin{array}{c}\text { less than } \\
46.94 \% \\
\end{array}$ & $\begin{array}{l}46.94 \% \text { to } \\
101.71 \% \\
\end{array}$ & $\begin{array}{c}101.72 \% \text { to } \\
334.72 \% \\
\end{array}$ & $\begin{array}{c}\text { more than } \\
334.72 \% \\
\end{array}$ & $\begin{array}{c}\text { Absent or } \\
\text { NM } \\
\end{array}$ \\
\hline 51 & e anterior and posterior & $\begin{array}{l}\text { less than } \\
2.03 \%\end{array}$ & $\begin{array}{l}2.03 \% \text { to } \\
99.39 \%\end{array}$ & $\begin{array}{l}99.40 \% \text { to } \\
315.69 \%\end{array}$ & $\begin{array}{c}\text { more than } \\
315.69 \%\end{array}$ & $\begin{array}{l}\text { Absent or } \\
\text { NM }\end{array}$ \\
\hline 52 & ter of the anterior and & $\begin{array}{c}\text { less than } \\
12.74 \%\end{array}$ & $\begin{array}{c}12.74 \% \text { to } \\
98.03 \%\end{array}$ & $\begin{array}{c}98.04 \% \text { to } \\
127.72 \% \\
\end{array}$ & $\begin{array}{c}\text { more than } \\
127.72 \% \\
\end{array}$ & $\begin{array}{c}\text { Absent or } \\
\text { NM }\end{array}$ \\
\hline 53 & th of the anterior channel and & $\begin{array}{c}\text { less than } \\
0.74 \% \\
\end{array}$ & $\begin{array}{c}0.74 \% \text { to } \\
18.10 \% \\
\end{array}$ & $\begin{array}{c}18.11 \% \text { to } \\
49.58 \%\end{array}$ & $\begin{array}{c}\text { more than } \\
49.58 \% \\
\end{array}$ & $\begin{array}{c}\text { Absent or } \\
\text { NM }\end{array}$ \\
\hline 54 & $\begin{array}{l}\text { th of the anterior channel and } \\
\text { Il }\end{array}$ & $\begin{array}{l}\text { less than } \\
8.29 \%\end{array}$ & $\begin{array}{c}8.29 \% \text { to } \\
13.72 \% \\
\end{array}$ & $\begin{array}{c}13.73 \% \text { to } \\
39.74 \%\end{array}$ & $\begin{array}{c}\text { more than } \\
39.74 \%\end{array}$ & $\begin{array}{c}\text { Absent or } \\
\text { NM }\end{array}$ \\
\hline 55 & $\begin{array}{l}\text { The ratio of perimeter of the anterior channel } \\
\text { and length of the shell }\end{array}$ & $\begin{array}{l}\text { less than } \\
4.21 \%\end{array}$ & $\begin{array}{l}4.21 \% \text { to } \\
23.25 \%\end{array}$ & $\begin{array}{c}23.26 \% \text { to } \\
47.04 \%\end{array}$ & $\begin{array}{c}\text { more than } \\
47.04 \%\end{array}$ & $\begin{array}{l}\text { Absent or } \\
\text { NM }\end{array}$ \\
\hline 56 & $\begin{array}{l}\text { The ratio of perimeter of the anterior channel } \\
\text { and perimeter of the shell }\end{array}$ & $\begin{array}{l}\text { less than } \\
1.40 \%\end{array}$ & $\begin{array}{l}1.40 \% \text { to } \\
9.61 \%\end{array}$ & $\begin{array}{l}9.62 \% \text { to } \\
17.95 \%\end{array}$ & $\begin{array}{l}\text { more than } \\
17.95 \%\end{array}$ & $\begin{array}{l}\text { Absent or } \\
\text { NM }\end{array}$ \\
\hline 57 & $\begin{array}{l}\text { The ratio of area of the anterior channel and } \\
\text { area of the shell }\end{array}$ & $\begin{array}{l}\text { less than } \\
0.04 \%\end{array}$ & $\begin{array}{l}0.04 \% \text { to } \\
1.58 \%\end{array}$ & $\begin{array}{l}1.59 \% \text { to } \\
7.00 \%\end{array}$ & $\begin{array}{c}\text { more than } \\
7.00 \%\end{array}$ & $\begin{array}{l}\text { Absent or } \\
\text { NM }\end{array}$ \\
\hline 58 & $\begin{array}{l}\text { The ratio of height of the posterior channel } \\
\text { and height of the shell }\end{array}$ & $\begin{array}{c}\text { less than } \\
11.05 \%\end{array}$ & $\begin{array}{c}11.05 \% \text { to } \\
18.82 \% \\
\end{array}$ & $\begin{array}{c}18.83 \% \text { to } \\
43.65 \%\end{array}$ & $\begin{array}{c}\text { more than } \\
43.65 \% \\
\end{array}$ & $\begin{array}{c}\text { Absent or } \\
\text { NM }\end{array}$ \\
\hline 59 & $\begin{array}{l}\text { The ratio of width of the posterior channel and } \\
\text { width of the shell }\end{array}$ & $\begin{array}{l}\text { less than } \\
5.72 \%\end{array}$ & $\begin{array}{l}5.72 \% \text { to } \\
13.49 \%\end{array}$ & $\begin{array}{c}13.50 \% \text { to } \\
36.22 \%\end{array}$ & $\begin{array}{c}\text { more than } \\
36.22 \%\end{array}$ & $\begin{array}{c}\text { Absent or } \\
\text { NM }\end{array}$ \\
\hline 60 & $\begin{array}{l}\text { The ratio of perimeter of the posterior channel } \\
\text { and length of the shell }\end{array}$ & $\begin{array}{l}\text { less than } \\
21.66 \%\end{array}$ & $\begin{array}{l}21.66 \% \text { to } \\
23.72 \% \\
\end{array}$ & $\begin{array}{l}23.73 \% \text { to } \\
53.03 \%\end{array}$ & $\begin{array}{c}\text { more than } \\
53.03 \% \\
\end{array}$ & $\begin{array}{c}\text { Absent or } \\
\text { NM }\end{array}$ \\
\hline 61 & $\begin{array}{l}\text { The ratio of perimeter of the posterior channel } \\
\text { and perimeter of the shell }\end{array}$ & $\begin{array}{l}\text { less than } \\
8.17 \%\end{array}$ & $\begin{array}{l}8.17 \% \text { to } \\
9.80 \%\end{array}$ & $\begin{array}{l}9.81 \% \text { to } \\
19.66 \%\end{array}$ & $\begin{array}{c}\text { more than } \\
19.66 \%\end{array}$ & $\begin{array}{l}\text { Absent or } \\
\text { NM }\end{array}$ \\
\hline 62 & $\begin{array}{l}\text { The ratio of area of the posterior channel and } \\
\text { area of the shell }\end{array}$ & $\begin{array}{l}\text { less than } \\
1.20 \% \\
\end{array}$ & $\begin{array}{l}1.20 \% \text { to } \\
1.59 \%\end{array}$ & $\begin{array}{c}1.60 \% \text { to } \\
6.45 \%\end{array}$ & $\begin{array}{c}\text { more than } \\
6.45 \%\end{array}$ & $\begin{array}{c}\text { Absent or } \\
\text { NM }\end{array}$ \\
\hline
\end{tabular}




\section{International Journal of Oceanography \& Aquaculture}

\begin{tabular}{|c|c|c|c|c|c|c|}
\hline 63 & $\begin{array}{l}\text { The ratio of height of the anterior channel and } \\
\text { width of the shell }\end{array}$ & $\begin{array}{c}\text { less than } \\
0.57 \%\end{array}$ & $\begin{array}{l}0.57 \% \text { to } \\
13.34 \%\end{array}$ & $\begin{array}{c}13.35 \% \text { to } \\
31.15 \%\end{array}$ & $\begin{array}{c}\text { more than } \\
31.15 \%\end{array}$ & $\begin{array}{c}\text { Absent or } \\
\text { NM }\end{array}$ \\
\hline 64 & $\begin{array}{l}\text { The ratio of width of the anterior channel and } \\
\text { length of the shell }\end{array}$ & $\begin{array}{c}\text { less than } \\
5.50 \%\end{array}$ & $\begin{array}{l}5.50 \% \text { to } \\
8.68 \%\end{array}$ & $\begin{array}{c}8.69 \% \text { to } \\
26.46 \%\end{array}$ & $\begin{array}{c}\text { more than } \\
26.46 \%\end{array}$ & $\begin{array}{c}\text { Absent or } \\
\text { NM }\end{array}$ \\
\hline 65 & $\begin{array}{l}\text { The ratio of width of the anterior channel and } \\
\text { width of the aperture }\end{array}$ & $\begin{array}{c}\text { less than } \\
23.79 \%\end{array}$ & $\begin{array}{l}23.79 \% \text { to } \\
48.25 \%\end{array}$ & $\begin{array}{c}48.26 \% \text { to } \\
149.03 \%\end{array}$ & $\begin{array}{c}\text { more than } \\
149.03 \%\end{array}$ & $\begin{array}{c}\text { Absent or } \\
\text { NM }\end{array}$ \\
\hline 66 & $\begin{array}{l}\text { The ratio of height of the anterior channel and } \\
\text { width of the aperture }\end{array}$ & $\begin{array}{c}\text { less than } \\
1.83 \%\end{array}$ & $\begin{array}{l}1.83 \% \text { to } \\
46.90 \%\end{array}$ & $\begin{array}{l}46.91 \% \text { to } \\
182.86 \%\end{array}$ & $\begin{array}{c}\text { more than } \\
182.86 \%\end{array}$ & $\begin{array}{c}\text { Absent or } \\
\text { NM }\end{array}$ \\
\hline 67 & $\begin{array}{l}\text { The ratio of height of the posterior channel } \\
\text { and width of the shell }\end{array}$ & $\begin{array}{l}\text { less than } \\
8.57 \%\end{array}$ & $\begin{array}{l}8.57 \% \text { to } \\
13.87 \% \\
\end{array}$ & $\begin{array}{c}13.88 \% \text { to } \\
38.95 \%\end{array}$ & $\begin{array}{c}\text { more than } \\
38.95 \% \\
\end{array}$ & \begin{tabular}{|c|} 
Absent or \\
NM
\end{tabular} \\
\hline 68 & $\begin{array}{l}\text { The ratio of width of the posterior channel and } \\
\text { length of the shell }\end{array}$ & $\begin{array}{c}\text { less than } \\
3.04 \% \\
\end{array}$ & $\begin{array}{l}3.04 \% \text { to } \\
8.54 \%\end{array}$ & $\begin{array}{l}8.55 \% \text { to } \\
23.36 \% \\
\end{array}$ & $\begin{array}{c}\text { more than } \\
23.36 \% \\
\end{array}$ & \begin{tabular}{|c|} 
Absent or \\
NM
\end{tabular} \\
\hline 69 & $\begin{array}{l}\text { The ratio of width of the posterior channel and } \\
\text { width of the aperture }\end{array}$ & $\begin{array}{c}\text { less than } \\
14.03 \% \\
\end{array}$ & $\begin{array}{c}14.03 \% \text { to } \\
47.44 \%\end{array}$ & $\begin{array}{c}47.45 \% \text { to } \\
136.78 \% \\
\end{array}$ & $\begin{array}{c}\text { more than } \\
136.78 \% \\
\end{array}$ & \begin{tabular}{|c|} 
Absent or \\
NM
\end{tabular} \\
\hline \multirow[t]{2}{*}{70} & $\begin{array}{l}\text { The ratio of height of the posterior channel } \\
\text { and width of the aperture }\end{array}$ & $\begin{array}{c}\text { less than } \\
20.81 \% \\
\end{array}$ & $\begin{array}{l}20.81 \% \text { to } \\
48.77 \%\end{array}$ & $\begin{array}{l}48.78 \% \text { to } \\
155.53 \% \\
\end{array}$ & $\begin{array}{c}\text { more than } \\
155.53 \% \\
\end{array}$ & \begin{tabular}{|c|}
$\begin{array}{c}\text { Absent or } \\
\text { NM }\end{array}$ \\
\end{tabular} \\
\hline & The ratio of shell aperture & & & & & \\
\hline 71 & The ratio of width and length of the aperture & $\begin{array}{c}\text { less than } \\
8.86 \%\end{array}$ & $\begin{array}{c}8.86 \% \text { to } \\
16.66 \%\end{array}$ & $\begin{array}{c}16.67 \% \text { to } \\
25.24 \%\end{array}$ & $\begin{array}{c}\text { more than } \\
25.24 \%\end{array}$ & $\begin{array}{c}\text { Absent or } \\
\text { NM }\end{array}$ \\
\hline 72 & $\begin{array}{l}\text { The ratio of width of the aperture and width } \\
\text { inner lip }\end{array}$ & $\begin{array}{l}\text { less than } \\
24.76 \%\end{array}$ & $\begin{array}{l}24.76 \% \text { to } \\
45.87 \%\end{array}$ & $\begin{array}{l}45.88 \% \text { to } \\
87.96 \%\end{array}$ & $\begin{array}{c}\text { more than } \\
87.96 \% \\
\end{array}$ & \begin{tabular}{|c|} 
Absent or \\
NM
\end{tabular} \\
\hline 73 & $\begin{array}{l}\text { The ratio of width of the aperture and width } \\
\text { outer lip }\end{array}$ & $\begin{array}{c}\text { less than } \\
35.99 \% \\
\end{array}$ & $\begin{array}{l}35.99 \% \text { to } \\
70.11 \%\end{array}$ & $\begin{array}{l}70.12 \% \text { to } \\
196.75 \%\end{array}$ & $\begin{array}{c}\text { more than } \\
196.75 \% \\
\end{array}$ & \begin{tabular}{|c|} 
Absent or \\
NM
\end{tabular} \\
\hline 74 & $\begin{array}{l}\text { The ratio of width of the aperture and width of } \\
\text { the shell }\end{array}$ & $\begin{array}{c}\text { less than } \\
16.18 \% \\
\end{array}$ & $\begin{array}{l}16.18 \% \text { to } \\
28.44 \%\end{array}$ & $\begin{array}{l}28.45 \% \text { to } \\
48.16 \%\end{array}$ & $\begin{array}{c}\text { more than } \\
48.16 \%\end{array}$ & $\begin{array}{c}\text { Absent or } \\
\text { NM }\end{array}$ \\
\hline 75 & $\begin{array}{l}\text { The ratio of length of the aperture and length } \\
\text { of the shell }\end{array}$ & $\begin{array}{c}\text { less than } \\
76.92 \%\end{array}$ & $\begin{array}{c}76.92 \% \text { to } \\
107.98 \%\end{array}$ & $\begin{array}{c}107.99 \% \text { to } \\
141.72 \%\end{array}$ & $\begin{array}{c}\text { more than } \\
141.72 \%\end{array}$ & \begin{tabular}{|c|} 
Absent or \\
NM
\end{tabular} \\
\hline 76 & $\begin{array}{l}\text { The ratio of width of the aperture and area of } \\
\text { the shell }\end{array}$ & $\begin{array}{c}\text { less than } \\
1.01 \% \\
\end{array}$ & $\begin{array}{c}1.01 \% \text { to } \\
1.85 \%\end{array}$ & $\begin{array}{c}1.86 \% \text { to } \\
4.39 \%\end{array}$ & $\begin{array}{c}\text { more than } \\
4.39 \%\end{array}$ & \begin{tabular}{|c|} 
Absent or \\
NM
\end{tabular} \\
\hline 77 & $\begin{array}{l}\text { The ratio of length of the aperture and area of } \\
\text { the shell }\end{array}$ & $\begin{array}{l}\text { less than } \\
7.66 \%\end{array}$ & $\begin{array}{l}7.66 \% \text { to } \\
11.12 \%\end{array}$ & $\begin{array}{c}11.13 \% \text { to } \\
20.54 \%\end{array}$ & $\begin{array}{l}\text { more than } \\
20.54 \%\end{array}$ & $\begin{array}{c}\text { Absent or } \\
\text { NM }\end{array}$ \\
\hline 78 & $\begin{array}{l}\text { The ratio of length of the aperture and } \\
\text { perimeter of the shell }\end{array}$ & $\begin{array}{c}\text { less than } \\
29.73 \%\end{array}$ & $\begin{array}{l}29.73 \% \text { to } \\
44.63 \%\end{array}$ & $\begin{array}{l}44.64 \% \text { to } \\
54.39 \%\end{array}$ & $\begin{array}{c}\text { more than } \\
54.39 \%\end{array}$ & $\begin{array}{c}\text { Absent or } \\
\text { NM }\end{array}$ \\
\hline 79 & $\begin{array}{l}\text { The ratio of width of the aperture and } \\
\text { perimeter of the shell }\end{array}$ & $\begin{array}{c}\text { less than } \\
3.57 \%\end{array}$ & $\begin{array}{l}3.57 \% \text { to } \\
7.44 \%\end{array}$ & $\begin{array}{l}7.45 \% \text { to } \\
11.59 \%\end{array}$ & $\begin{array}{c}\text { more than } \\
11.59 \%\end{array}$ & $\begin{array}{c}\text { Absent or } \\
\text { NM }\end{array}$ \\
\hline 80 & $\begin{array}{l}\text { The ratio of width of the aperture and height } \\
\text { of the shell }\end{array}$ & $\begin{array}{c}\text { less than } \\
19.21 \%\end{array}$ & $\begin{array}{l}19.21 \% \text { to } \\
38.60 \%\end{array}$ & $\begin{array}{l}38.61 \% \text { to } \\
58.64 \%\end{array}$ & $\begin{array}{c}\text { more than } \\
58.64 \%\end{array}$ & $\begin{array}{c}\text { Absent or } \\
\text { NM }\end{array}$ \\
\hline 81 & $\begin{array}{l}\text { The ratio of length of the aperture and height } \\
\text { of the shell }\end{array}$ & $\begin{array}{l}\text { less than } \\
180.34 \%\end{array}$ & $\begin{array}{c}180.34 \% \text { to } \\
231.63 \%\end{array}$ & $\begin{array}{c}231.64 \% \text { to } \\
343.63 \%\end{array}$ & $\begin{array}{c}\text { more than } \\
343.63 \%\end{array}$ & $\begin{array}{c}\text { Absent or } \\
\text { NM }\end{array}$ \\
\hline \multirow[t]{2}{*}{82} & $\begin{array}{l}\text { The ratio of length of the aperture and width } \\
\text { of the shell }\end{array}$ & $\begin{array}{l}\text { less than } \\
126.72 \% \\
\end{array}$ & $\begin{array}{c}126.72 \% \text { to } \\
170.67 \%\end{array}$ & $\begin{array}{c}170.68 \% \text { to } \\
230.86 \% \\
\end{array}$ & $\begin{array}{c}\text { more than } \\
230.86 \% \\
\end{array}$ & \begin{tabular}{|c|} 
Absent or \\
NM
\end{tabular} \\
\hline & The ratio of shell lips & & & & & \\
\hline 83 & The ratio of width of the inner and outer lips & $\begin{array}{c}\text { less than } \\
97.41 \%\end{array}$ & $\begin{array}{l}97.41 \% \text { to } \\
152.84 \%\end{array}$ & $\begin{array}{c}152.85 \% \text { to } \\
314.16 \%\end{array}$ & $\begin{array}{c}\text { more than } \\
314.16 \%\end{array}$ & \begin{tabular}{|c} 
Absent or \\
NM
\end{tabular} \\
\hline 84 & $\begin{array}{l}\text { The ratio of width of the inner lip and width of } \\
\text { the shell }\end{array}$ & $\begin{array}{l}\text { less than } \\
32.28 \%\end{array}$ & $\begin{array}{l}32.28 \% \text { to } \\
62.00 \%\end{array}$ & $\begin{array}{l}62.01 \% \text { to } \\
81.73 \%\end{array}$ & $\begin{array}{c}\text { more than } \\
81.73 \%\end{array}$ & $\begin{array}{c}\text { Absent or } \\
\text { NM }\end{array}$ \\
\hline 85 & $\begin{array}{l}\text { The ratio of width of the inner lip and height of } \\
\text { the shell }\end{array}$ & $\begin{array}{c}\text { less than } \\
45.97 \%\end{array}$ & $\begin{array}{l}45.97 \% \text { to } \\
84.14 \%\end{array}$ & $\begin{array}{c}84.15 \% \text { to } \\
124.06 \%\end{array}$ & $\begin{array}{c}\text { more than } \\
124.06 \%\end{array}$ & $\begin{array}{c}\text { Absent or } \\
\text { NM }\end{array}$ \\
\hline 86 & The ratio of width of the inner lip and length of & less than & $20.64 \%$ to & $39.24 \%$ to & more than & Absent or \\
\hline
\end{tabular}




\section{International Journal of Oceanography \& Aquaculture}

\begin{tabular}{|c|c|c|c|c|c|c|}
\hline & the shell & $20.64 \%$ & $39.23 \%$ & $51.80 \%$ & $51.80 \%$ & NM \\
\hline 87 & $\begin{array}{l}\text { The ratio of width of the inner lip and } \\
\text { perimeter of the shell }\end{array}$ & $\begin{array}{l}\text { less than } \\
7.21 \%\end{array}$ & $\begin{array}{l}7.21 \% \text { to } \\
16.21 \%\end{array}$ & $\begin{array}{c}16.22 \% \text { to } \\
18.75 \%\end{array}$ & $\begin{array}{c}\text { more than } \\
18.75 \%\end{array}$ & $\begin{array}{l}\text { Absent or } \\
\text { NM }\end{array}$ \\
\hline 88 & $\begin{array}{l}\text { The ratio of width of the inner lip and area of } \\
\text { the shell }\end{array}$ & $\begin{array}{l}\text { less than } \\
2.01 \%\end{array}$ & $\begin{array}{l}2.01 \% \text { to } \\
4.04 \%\end{array}$ & $\begin{array}{c}4.05 \% \text { to } \\
7.47 \%\end{array}$ & $\begin{array}{c}\text { more than } \\
7.47 \%\end{array}$ & $\begin{array}{c}\text { Absent or } \\
\text { NM }\end{array}$ \\
\hline 89 & $\begin{array}{l}\text { The ratio of width of the outer lip and width of } \\
\text { the shell }\end{array}$ & $\begin{array}{c}\text { less than } \\
21.73 \% \\
\end{array}$ & $\begin{array}{c}21.73 \% \text { to } \\
40.56 \%\end{array}$ & $\begin{array}{l}40.57 \% \text { to } \\
53.29 \%\end{array}$ & $\begin{array}{c}\text { more than } \\
53.29 \% \\
\end{array}$ & $\begin{array}{c}\text { Absent or } \\
\text { NM }\end{array}$ \\
\hline 90 & $\begin{array}{l}\text { The ratio of width of the outer lip and height of } \\
\text { the shell }\end{array}$ & $\begin{array}{c}\text { less than } \\
23.22 \%\end{array}$ & $\begin{array}{l}23.22 \% \text { to } \\
55.05 \%\end{array}$ & $\begin{array}{l}55.06 \% \text { to } \\
76.53 \%\end{array}$ & $\begin{array}{c}\text { more than } \\
76.53 \%\end{array}$ & $\begin{array}{l}\text { Absent or } \\
\text { NM }\end{array}$ \\
\hline 91 & $\begin{array}{l}\text { The ratio of width of the outer lip and length of } \\
\text { the shell }\end{array}$ & $\begin{array}{c}\text { less than } \\
10.95 \%\end{array}$ & $\begin{array}{c}10.95 \% \text { to } \\
25.66 \%\end{array}$ & $\begin{array}{c}25.67 \% \text { to } \\
34.33 \%\end{array}$ & $\begin{array}{c}\text { more than } \\
34.33 \%\end{array}$ & $\begin{array}{l}\text { Absent or } \\
\text { NM }\end{array}$ \\
\hline 92 & $\begin{array}{l}\text { The ratio of width of the outer lip and } \\
\text { perimeter of the shell }\end{array}$ & $\begin{array}{c}\text { less than } \\
3.82 \% \\
\end{array}$ & $\begin{array}{l}3.82 \% \text { to } \\
10.61 \%\end{array}$ & $\begin{array}{c}10.62 \% \text { to } \\
12.69 \%\end{array}$ & $\begin{array}{c}\text { more than } \\
12.69 \% \\
\end{array}$ & $\begin{array}{c}\text { Absent or } \\
\text { NM }\end{array}$ \\
\hline 93 & $\begin{array}{l}\text { The ratio of width of the outer lip and area of } \\
\text { the shell }\end{array}$ & $\begin{array}{c}\text { less than } \\
1.06 \% \\
\end{array}$ & $\begin{array}{l}1.06 \% \text { to } \\
2.64 \%\end{array}$ & $\begin{array}{l}2.65 \% \text { to } \\
5.04 \%\end{array}$ & $\begin{array}{c}\text { more than } \\
5.04 \% \\
\end{array}$ & $\begin{array}{c}\text { Absent or } \\
\text { NM }\end{array}$ \\
\hline 94 & $\begin{array}{l}\text { The ratio of width of the inner lip and length of } \\
\text { the aperture }\end{array}$ & $\begin{array}{c}\text { less than } \\
18.80 \%\end{array}$ & $\begin{array}{c}18.80 \% \text { to } \\
36.33 \%\end{array}$ & $\begin{array}{c}36.34 \% \text { to } \\
46.56 \%\end{array}$ & $\begin{array}{c}\text { more than } \\
46.56 \%\end{array}$ & $\begin{array}{l}\text { Absent or } \\
\text { NM }\end{array}$ \\
\hline \multirow[t]{2}{*}{95} & $\begin{array}{l}\text { The ratio of width of the outer lip and length of } \\
\text { the aperture }\end{array}$ & $\begin{array}{c}\text { less than } \\
10.29 \% \\
\end{array}$ & $\begin{array}{c}10.29 \% \text { to } \\
23.77 \% \\
\end{array}$ & $\begin{array}{c}23.78 \% \text { to } \\
32.31 \% \\
\end{array}$ & $\begin{array}{c}\text { more than } \\
32.31 \% \\
\end{array}$ & $\begin{array}{c}\text { Absent or } \\
\text { NM }\end{array}$ \\
\hline & The ratio of shell surface (dorsal outline) & & & & & \\
\hline 96 & io of perimeter and area of the shell & $\begin{array}{c}\text { less than } \\
19.88 \% \\
\end{array}$ & $\begin{array}{c}19.88 \% \text { to } \\
24.91 \%\end{array}$ & $\begin{array}{l}24.92 \% \text { to } \\
46.08 \%\end{array}$ & $\begin{array}{c}\text { more than } \\
46.08 \%\end{array}$ & $\begin{array}{c}\text { Absent or } \\
\text { NM }\end{array}$ \\
\hline 97 & The ratio of length and perimeter of the shell & $\begin{array}{c}\text { less than } \\
25.94 \%\end{array}$ & $\begin{array}{c}25.94 \% \text { to } \\
41.33 \%\end{array}$ & $\begin{array}{c}41.34 \% \text { to } \\
47.67 \%\end{array}$ & $\begin{array}{c}\text { more than } \\
47.67 \%\end{array}$ & $\begin{array}{c}\text { Absent or } \\
\text { NM }\end{array}$ \\
\hline 98 & The ratio of length and area of the shell surface & $\begin{array}{c}\text { less than } \\
6.72 \% \\
\end{array}$ & $\begin{array}{l}6.72 \% \text { to } \\
10.29 \% \\
\end{array}$ & $\begin{array}{c}10.30 \% \text { to } \\
17.64 \%\end{array}$ & $\begin{array}{c}\text { more than } \\
17.64 \% \\
\end{array}$ & $\begin{array}{c}\text { Absent or } \\
\text { NM }\end{array}$ \\
\hline 99 & The ratio of weight and perimeter of the shell & $\begin{array}{c}\text { less than } \\
0.40 \%\end{array}$ & $\begin{array}{c}0.40 \% \text { to } \\
3.29 \%\end{array}$ & $\begin{array}{c}3.30 \% \text { to } \\
4.65 \%\end{array}$ & $\begin{array}{l}\text { more than } \\
4.65 \%\end{array}$ & $\begin{array}{l}\text { Absent or } \\
\text { NM }\end{array}$ \\
\hline 100 & $\begin{array}{l}\text { The ratio of weight and area of the shell } \\
\text { surface }\end{array}$ & $\begin{array}{c}\text { less than } \\
0.12 \% \\
\end{array}$ & $\begin{array}{c}0.12 \% \text { to } \\
0.82 \%\end{array}$ & $\begin{array}{c}0.83 \% \text { to } \\
1.08 \%\end{array}$ & $\begin{array}{c}\text { more than } \\
1.08 \% \\
\end{array}$ & $\begin{array}{c}\text { Absent or } \\
\text { NM }\end{array}$ \\
\hline 101 & $\begin{array}{l}\text { The ratio of width and perimeter of the shell } \\
\text { surface }\end{array}$ & $\begin{array}{c}\text { less than } \\
16.57 \% \\
\end{array}$ & $\begin{array}{c}16.57 \% \text { to } \\
26.15 \%\end{array}$ & $\begin{array}{l}26.16 \% \text { to } \\
30.25 \%\end{array}$ & $\begin{array}{c}\text { more than } \\
30.25 \% \\
\end{array}$ & $\begin{array}{c}\text { Absent or } \\
\text { NM }\end{array}$ \\
\hline 102 & The ratio of width and area of the shell surface & $\begin{array}{c}\text { less than } \\
4.45 \%\end{array}$ & $\begin{array}{c}4.45 \% \text { to } \\
6.51 \%\end{array}$ & $\begin{array}{c}6.52 \% \text { to } \\
11.34 \%\end{array}$ & $\begin{array}{c}\text { more than } \\
11.34 \%\end{array}$ & $\begin{array}{c}\text { Absent or } \\
\text { NM }\end{array}$ \\
\hline 103 & $\begin{array}{l}\text { The ratio of height and perimeter of the shell } \\
\text { surface }\end{array}$ & $\begin{array}{c}\text { less than } \\
11.75 \% \\
\end{array}$ & $\begin{array}{c}11.75 \% \text { to } \\
19.27 \%\end{array}$ & $\begin{array}{c}19.28 \% \text { to } \\
22.10 \%\end{array}$ & $\begin{array}{l}\text { more than } \\
22.10 \% \\
\end{array}$ & $\begin{array}{c}\text { Absent or } \\
\text { NM }\end{array}$ \\
\hline 104 & The ratio of height and area of the shell surface & $\begin{array}{c}\text { less than } \\
3.21 \%\end{array}$ & $\begin{array}{l}3.21 \% \text { to } \\
4.80 \%\end{array}$ & $\begin{array}{l}4.81 \% \text { to } \\
9.12 \%\end{array}$ & $\begin{array}{l}\text { more than } \\
9.12 \%\end{array}$ & $\begin{array}{l}\text { Absent or } \\
\text { NM }\end{array}$ \\
\hline
\end{tabular}

Table 3: The test characters of MRC, Cypraea annulus and its state based on morphometric traits for ordinal data type. Notes: ratio was determined by reference:

1. less than least value (less than minimum value)

2. Least value to mode (minimum to mode value)

3. Mode value to maximum (mode to maximum value)

4. Greater than maximum value

5. Absent atau NM.

(If no mode value or $\mathrm{N} / \mathrm{A}$, then used the median value)

NM (No measured) 


\section{International Journal of Oceanography \& Aquaculture}

\begin{tabular}{|c|c|c|c|}
\hline \multirow{2}{*}{ Num. } & \multirow{2}{*}{ Character description } & \multicolumn{2}{|c|}{ Character states (binary) } \\
\hline & & 1 & $\mathbf{0}$ \\
\hline & The ratio of shell weight & & \\
\hline 1 & The ratio of weight and the length of the shell & more than or equal to $5.39 \%$ & less than $5.39 \%$ \\
\hline 2 & The ratio of weight and the width of the shell & more than or equal to $8.27 \%$ & less than $8.27 \%$ \\
\hline 3 & The ratio of weight and the height of the shell & more than or equal to $11.07 \%$ & less than $11.07 \%$ \\
\hline 4 & The ratio of weight and length plus the width of the shell & more than or equal to $3.26 \%$ & less than $3.26 \%$ \\
\hline 5 & The ratio of weight and length plus the height of the shell & more than or equal to $3.62 \%$ & less than $3.62 \%$ \\
\hline 6 & The ratio weight and width plus the height of the shell & more than or equal to $4.73 \%$ & less than $4.73 \%$ \\
\hline 7 & The ratio of weight and length plus width plus height of the shell & more than or equal to $2.52 \%$ & less than $2.52 \%$ \\
\hline 8 & $\begin{array}{l}\text { The ratio of weight and length multiplied by the width of the } \\
\text { shell }\end{array}$ & more than or equal to $0.42 \%$ & less than $0.42 \%$ \\
\hline 9 & $\begin{array}{l}\text { The ratio of weight and length multiplied by the height of the } \\
\text { shell }\end{array}$ & more than or equal to $0.56 \%$ & less than $0.56 \%$ \\
\hline 10 & $\begin{array}{l}\text { The ratio of weight and width multiplied by the height of the } \\
\text { shell }\end{array}$ & more than or equal to $0.86 \%$ & less than $0.86 \%$ \\
\hline \multirow[t]{2}{*}{11} & $\begin{array}{l}\text { The ratio of weight and length multiplied by the width of the } \\
\text { height of the shell }\end{array}$ & more than or equal to $0.05 \%$ & less than $0.05 \%$ \\
\hline & The ratio of shell length & & \\
\hline 12 & The ratio of the length and weight of the shell & more than or equal to $2541.57 \%$ & $\begin{array}{l}\text { less than } \\
2541.57 \%\end{array}$ \\
\hline 13 & The ratio of the length and width of the shell & more than or equal to $155.04 \%$ & $\begin{array}{l}\text { less than } \\
155.04 \% \\
\end{array}$ \\
\hline 14 & The ratio of the length and height of the shell & more than or equal to $206.74 \%$ & $\begin{array}{l}\text { less than } \\
206.74 \% \\
\end{array}$ \\
\hline 15 & The ratio of length and length plus shell width & more than or equal to $60.72 \%$ & less than $60.72 \%$ \\
\hline 16 & The ratio of length and length plus height of the shell & more than or equal to $67.32 \%$ & less than $67.32 \%$ \\
\hline 17 & The ratio of length and width plus the height of the shell & more than or equal to $88.53 \%$ & less than $88.53 \%$ \\
\hline 18 & The ratio of length and length plus width plus height of the shel & more than or equal to $46.91 \%$ & less than $46.91 \%$ \\
\hline 19 & $\begin{array}{l}\text { The ratio of length and length multiplied by the width of the } \\
\text { shell }\end{array}$ & more than or equal to $8.72 \%$ & less than $8.72 \%$ \\
\hline 20 & $\begin{array}{l}\text { The ratio of length and length multiplied by the height of the } \\
\text { shell }\end{array}$ & more than or equal to $11.62 \%$ & less than $11.62 \%$ \\
\hline 21 & $\begin{array}{l}\text { The ratio of length and width multiplied by the height of the } \\
\text { shell }\end{array}$ & more than or equal to $18.05 \%$ & less than $18.05 \%$ \\
\hline \multirow[t]{2}{*}{22} & $\begin{array}{l}\text { The ratio of length and length times the width of the height of } \\
\text { the shell }\end{array}$ & more than or equal to $1.08 \%$ & less than $1.08 \%$ \\
\hline & The ratio of shell width & & \\
\hline 23 & The ratio of the width and weight of the shell & more than or equal to $1637.35 \%$ & $\begin{array}{l}\text { less than } \\
1637.35 \%\end{array}$ \\
\hline 24 & e width a & more than or equal to $64.80 \%$ & less than $64.80 \%$ \\
\hline 25 & The ratio of width and height of the & more than or equ & $\begin{array}{l}\text { less than } \\
133.50 \%\end{array}$ \\
\hline 26 & The ratio of width and length plus width of the shell & more than or equal to $39.28 \%$ & less than $39.28 \%$ \\
\hline 27 & The ratio of width and length plus the height of the shell & more than or equal to $43.58 \%$ & less than $43.58 \%$ \\
\hline 28 & The ratio of width and width plus shell height & more than or equal to $57.13 \%$ & less than $57.13 \%$ \\
\hline 29 & The ratio of width and length plus width plus height of the shell & more than or equal to $30.33 \%$ & less than $30.33 \%$ \\
\hline
\end{tabular}




\section{International Journal of Oceanography \& Aquaculture}

\begin{tabular}{|c|c|c|c|}
\hline 30 & The ratio of width and length multiplied by the width of the shell & more than or equal to $5.63 \%$ & less than $5.63 \%$ \\
\hline 31 & The ratio of width and length times the height of the shell & more than or equal to $7.51 \%$ & less than $7.51 \%$ \\
\hline 32 & The ratio of width and width multiplied by the height of the shell & more than or equal to $11.62 \%$ & less than $11.62 \%$ \\
\hline \multirow[t]{2}{*}{33} & $\begin{array}{l}\text { The ratio of width and length times the width of the height of the } \\
\text { shell }\end{array}$ & more than or equal to $0.70 \%$ & less than $0.70 \%$ \\
\hline & The ratio of shell height & & \\
\hline 34 & The ratio of height and weight of the shell & more than or equal to $1234.20 \%$ & $\begin{array}{l}\text { less than } \\
1234.20 \%\end{array}$ \\
\hline 35 & The ratio of height and length of the shell & more than or equal to $48.64 \%$ & less than $48.64 \%$ \\
\hline 36 & The ratio of height and width of the shell & more than or equal to $75.14 \%$ & less than $75.14 \%$ \\
\hline 37 & The ratio of height and length plus the width of the shell & more than or equal to $29.49 \%$ & less than $29.49 \%$ \\
\hline 38 & The ratio of height and length plus the height of the shell & more than or equal to $32.68 \%$ & less than $32.68 \%$ \\
\hline 39 & The ratio of height and width plus the height of the shell & more than or equal to $42.87 \%$ & less than $42.87 \%$ \\
\hline 40 & The ratio of height and length plus width plus height of the shell & more than or equal to $22.76 \%$ & less than $22.76 \%$ \\
\hline 41 & $\begin{array}{l}\text { The ratio of height and length multiplied by the width of the } \\
\text { shell }\end{array}$ & more than or equal to $4.24 \%$ & less than $4.24 \%$ \\
\hline 42 & $\begin{array}{l}\text { The ratio of height and length multiplied by the height of the } \\
\text { shell }\end{array}$ & more than or equal to $5.63 \%$ & less than $5.63 \%$ \\
\hline 43 & $\begin{array}{l}\text { The ratio of height and width multiplied by the height of the } \\
\text { shell }\end{array}$ & more than or equal to $8.72 \%$ & less than $8.72 \%$ \\
\hline \multirow[t]{2}{*}{44} & $\begin{array}{l}\text { The ratio of height and length times the width of the height of } \\
\text { the shell }\end{array}$ & more than or equal to $0.52 \%$ & less than $0.52 \%$ \\
\hline & The ratio of shell channel & & \\
\hline 45 & The ratio of height and width of the anterior channel & more than or equal to $76.54 \%$ & less than $76.54 \%$ \\
\hline 46 & The ratio of area and perimeter of the anterior channel & more than or equal to $80.31 \%$ & less than $80.31 \%$ \\
\hline 47 & The ratio of height and width of the posterior channel & more than or equal to $86.34 \%$ & less th \\
\hline 48 & The ratio of area and perimeter of the anterior channel & more than or equal to $63.87 \%$ & less than $63.87 \%$ \\
\hline 49 & The ratio of height of the anterior and posterior channel & more than or equal to $73.93 \%$ & less than $73.93 \%$ \\
\hline 50 & The ratio of width of the anterior and posterior & more than or equal $\mathrm{t}$ & $\begin{array}{l}\text { less than } \\
114.92 \%\end{array}$ \\
\hline 51 & The ratio of area of the anterior and posterior channel & more than or equal to $87.39 \%$ & less than $87.39 \%$ \\
\hline 52 & The ratio of perimeter of the anterior and posterior channel & more than or equal to $83.68 \%$ & less than $83.68 \%$ \\
\hline 53 & The ratio of height of the anterior channel and height of the shell & more than or equal to $19.10 \%$ & less than $19.10 \%$ \\
\hline 54 & The ratio of width of the anterior channel and width of the shell & more than or equal to $19.35 \%$ & less than $19.35 \%$ \\
\hline 55 & $\begin{array}{l}\text { The ratio of perimeter of the anterior channel and length of the } \\
\text { shell }\end{array}$ & more than or equal to $27.38 \%$ & less than 27.38 \\
\hline 56 & $\begin{array}{l}\text { The ratio of perimeter of the anterior channel and perimeter of } \\
\text { the shell }\end{array}$ & more than or equal to $10.21 \%$ & less than $10.21 \%$ \\
\hline 57 & The ratio of area of the anterior channel and area of the shell & nore than or equal to $2.24 \%$ & less than $2.24 \%$ \\
\hline 58 & $\begin{array}{l}\text { The ratio of height of the posterior channel and height of the } \\
\text { shell }\end{array}$ & more than or equal to $26.13 \%$ & less than 26.13 \\
\hline 59 & The ratio of width of the posterior channel and width of the shell & $17.17 \%$ & less than 17.17 \\
\hline 60 & $\begin{array}{l}\text { The ratio of perimeter of the posterior channel and length of the } \\
\text { shell }\end{array}$ & more than or equal to $33.01 \%$ & less than 33.01 \\
\hline 61 & $\begin{array}{l}\text { The ratio of perimeter of the posterior channel and perimeter of } \\
\text { the shell }\end{array}$ & more than or equal to $12.20 \%$ & less than 12.20 \\
\hline 62 & The ratio of area of the posterior channel and area of the shell & more than or equal to $2.54 \%$ & less than $2.54 \%$ \\
\hline
\end{tabular}




\section{International Journal of Oceanography \& Aquaculture}

\begin{tabular}{|c|c|c|c|}
\hline 63 & he ratio of height of the anterior channel and width of the shell & more than or equal to $14.32 \%$ & less than $14.32 \%$ \\
\hline 64 & The ratio of width of the anterior channel and length of the shell & more than or equal to $12.51 \%$ & less than $12.51 \%$ \\
\hline 65 & $\begin{array}{l}\text { The ratio of width of the anterior channel and width of the } \\
\text { aperture }\end{array}$ & more than or equal to $67.86 \%$ & less than $67.86 \%$ \\
\hline 66 & $\begin{array}{l}\text { The ratio of height of the anterior channel and width of the } \\
\text { aperture }\end{array}$ & more than or equal to $50.71 \%$ & less than $50.71 \%$ \\
\hline 67 & $\begin{array}{l}\text { The ratio of height of the posterior channel and width of the } \\
\text { shell }\end{array}$ & more than or eq & less than $19.60 \%$ \\
\hline 68 & $\begin{array}{l}\text { The ratio of width of the posterior channel and length of the } \\
\text { shell }\end{array}$ & more than or equal to $11.12 \%$ & less than $11.12 \%$ \\
\hline 69 & $\begin{array}{l}\text { The ratio of width of the posterior channel and width of the } \\
\text { aperture }\end{array}$ & more than or equal to $60.15 \%$ & less thar \\
\hline \multirow[t]{2}{*}{70} & $\begin{array}{l}\text { The ratio of height of the posterior channel and width of the } \\
\text { aperture }\end{array}$ & more than or e & less t \\
\hline & The ratio of shell aperture & & \\
\hline 71 & The ratio of width and length of & more & less \\
\hline 72 & The ratio of width of the aperture and width inner lip & more than or equal to $47.12 \%$ & less than $47.12 \%$ \\
\hline 73 & The ratio of width of the aperture and width outer lip & more than or equal to $75.98 \%$ & less than $75.98 \%$ \\
\hline 74 & and width of the & $29.17 \%$ & less t \\
\hline 75 & The ratio of length of the aperture and length of the shell & more than or e & $\begin{array}{l}\text { less than } \\
110.97 \% \\
\end{array}$ \\
\hline 76 & The ratio of width of th & l to $2.02 \%$ & less than $2.02 \%$ \\
\hline 77 & The ratio of length of the & more than or equal to $11.79 \%$ & n $11.79 \%$ \\
\hline 78 & The ratio of length of the aperture and perimeter of the shell & more than or equal to $41.13 \%$ & less than $41.13 \%$ \\
\hline 79 & The ratio of width of the aperture and perimeter of the shell & more than or equal to $6.98 \%$ & less than $6.98 \%$ \\
\hline 80 & The ratio of width of the aperture and height of the shell & to $38.83 \%$ & less than $38.83 \%$ \\
\hline 81 & The ratio of length of the aperture and height of the shell & more than or equal to $228.73 \%$ & $\begin{array}{l}\text { less than } \\
228.73 \%\end{array}$ \\
\hline \multirow[t]{2}{*}{82} & The ratio of length of the aperture and width of the shell & more than or equal to $171.66 \%$ & $\begin{array}{l}\text { less than } \\
171.66 \%\end{array}$ \\
\hline & $T$ & & \\
\hline 83 & The ratio of width of the inner and outer lips & more than or equal to $160.95 \%$ & $\begin{array}{l}\text { less than } \\
160.95 \%\end{array}$ \\
\hline 84 & The ratio of width of th & l to $62.02 \%$ & less than $62.02 \%$ \\
\hline 85 & The ratio of width of the inner lip and height of the shell & more than or equal to $82.69 \%$ & less than $82.69 \%$ \\
\hline 86 & The ratio of width of the inner lip and length of the shell & more than or equal to $40.16 \%$ & less than $40.16 \%$ \\
\hline 87 & The ratio of width of the inner lip and perimeter of the sh & more than or equal to $14.87 \%$ & less than $14.87 \%$ \\
\hline 88 & The ratio of width of the inner lip and area of the shell & more than or equal to $4.25 \%$ & less than $4.25 \%$ \\
\hline 89 & The ratio of width of the outer lip and width of the shell & more than or equal to $39.22 \%$ & less than $39.22 \%$ \\
\hline 90 & The ratio of width of the outer lip and height of the shell & more than or equal to $52.28 \%$ & less than $52.28 \%$ \\
\hline 91 & The ratio of width of the outer lip and length of the shell & more than or equal to $25.43 \%$ & less than $25.43 \%$ \\
\hline 92 & The ratio of width of the outer lip and perimeter of the shell & more than or equal to $9.44 \%$ & less than $9.44 \%$ \\
\hline 93 & The ratio of width of the outer lip and area of the shell & more than or equal to $2.67 \%$ & less than $2.67 \%$ \\
\hline 94 & 94. The ratio of width of the inner lip and length of the aperture & more than or equal to $36.24 \%$ & less than $36.24 \%$ \\
\hline \multirow[t]{2}{*}{95} & 95. The ratio of width of the outer lip and length of the aperture & more than or equal to $22.91 \%$ & less than $22.91 \%$ \\
\hline & The ratio of shell surface (dorsal outline) & & \\
\hline
\end{tabular}




\section{International Journal of Oceanography \& Aquaculture}

\begin{tabular}{|c|l|c|c|}
\hline 96 & The ratio of perimeter and area of the shell surface & more than or equal to $28.69 \%$ & less than $28.69 \%$ \\
\hline 97 & The ratio of length and perimeter of the shell & more than or equal to $37.16 \%$ & less than $37.16 \%$ \\
\hline 98 & The ratio of length and area of the shell surface & more than or equal to $10.64 \%$ & less than $10.64 \%$ \\
\hline 99 & The ratio of length and area of the shell surface & more than or equal to $2.02 \%$ & less than $2.02 \%$ \\
\hline 100 & The ratio of weight and area of the shell surface & more than or equal to $0.52 \%$ & less than $0.52 \%$ \\
\hline 101 & The ratio of width and perimeter of the shell surface & more than or equal to $24.02 \%$ & less than $24.02 \%$ \\
\hline 102 & The ratio of width and area of the shell surface & more than or equal to $6.87 \%$ & less than $6.87 \%$ \\
\hline 103 & The ratio of height and perimeter of the shell surface & more than or equal to $18.03 \%$ & less than $18.03 \%$ \\
\hline 104 & The ratio of height and area of the shell surface & more than or equal to 5.16\% & less than $5.16 \%$ \\
\hline
\end{tabular}

Table 4: The test characters of MRC, Cypraea annulus and its state based on morphometric traits for binary data type. Notes: The value used is the mode value, if there is no mode (N / A), then was used the median value.

\section{Data Analysis}

The encoding of the test trait in this study based on three data types i.e., binary, ordinal and numeric. The binary data type consists of two trait state that is "the same as the mode values" and "not the same as the mode". If there is no value of mode, then used the median value. Ordinal data type consists of five categories of test traits, while the numerical data type consists of measured quantitative data. The binary data type coded 1 or positive $(+)$ and code 0 or negative $(-)$, ordinal data type coded or labeled 1 (smaller than the least value), 2 (least value to mode value), 3 (mode value to the largest value), 4 (greater than the largest value) and 5 (absent or no measured), while the numerical data type calculated the mean. Standardization or weighting of quantitative traits in both ordinal and numerical data, calculated using the formula proposed by Sokal and Sneath [20] and Dunn \& Everitt [66]. All trait and subpopulation data arranged in a data set of next matrix, where $n$ is trait and $t$ is subpopulation to calculate the coefficient of similarity between subpopulation pair according to the trait data type tested.

Calculation of similarity coefficient for binary data type using Jaccard coefficient. The calculation based on a pair of 32 subpopulations, trait classes, and test trait data types. Distribution coefficient values are arranged in 10 intervals coefficient values are: 0.00 to $0.29,0.30$ to 0.49 , 0.50 to $0.69,0.70$ to $0.74,0.75$ to $0.84,0.85$ to $0.89,0.90$ to 0.94 , and 0.95 to 1.00 . The calculations for ordinal data used Spearman correlation coefficients, whereas the coefficients of similarity for numerical data types use the Pearson correlation coefficient [11,67]. The resulting similarity coefficient was then created a matrix similarity to display the similarity value of each subpopulation with each other. Furthermore, based on the similarity matrix did subpopulation grouping with the method of agglomerative hierarchical clustering $[66,68]$. The clustering algorithm used in this research was the UPGMA method and Ward method, where the unity between the subpopulation on the basis of the average value so that there will be a fusion or fusion subpopulation. The subpopulation smelter results in a simple hierarchy in the form of a phenotypic taxa level displayed in the form of a phenogram $[69,20]$.

Subpopulation smelter results into taxa data in the form of phenogram, then drawn a line at the level of the coefficient of similarity and phenetic distance to obtain the number of taxa levels represented by the subpopulation chosen based on the similarity of all the traits tested. The similarity level data on the phenogram was arranged in the phenogram evaluation matrix to perform the cophenetic correlation analysis with the initial similarity matrix. The result of the matrix evaluation of phenogram and initial similarity matrix was used to determine the Pearson correlation coefficient. The correlation coefficient value of $\mathrm{R}$ arithmetic was considered acceptable and accountable as the classification of taxa if $\mathrm{R}$ arithmetic $\geq 0.60$ or $60 \%[70,20]$.

The mapping of MTC aimed to describe the position of one subpopulation compared to the other subpopulations. Configuration maps prepared and analyzed using multidimension scaling, MDS [66,71]. The presence of subpopulations in the same quadrant based on the similarity of the subpopulation, if two subpopulations have many similarities, then both will lie adjacent even in one ordinate with another in a particular quadrant.

\section{Statistics}

Data processed and analyzed using multitrait or multivariate analysis i.e factor analysis, PCA, clustering analysis, and MDS $[66,68,69,71]$. Assumption test was done to know whether all data had fulfilled and workable to do multivariate analysis that was with normality test; 
test of data homogeneity; test of sufficiency factor Kaiser Meyer Oikin or KMO; freedom test between variables; as well as multicollinearity test. The charactization of the influence of trait measurement units done by transforming the data according to the needs of the analysis and the software was used. Statistical analysis used Microsoft Excel software ver. 2013, Xlstat release 2014, PAST version 3.1, MVSP ver. 3.1 and Minitab ver.17.

\section{Results}

\section{Phenotypic Expression of Morphometric 32 Subpopulations of MRC}

The PEM was a trait expression associated with variations and changes in the size of the body's shape and structure of the organism or measuring methods. MT in principle measures the traits on certain parts of the body surface of the organism. Each individual has a specific and different size between one organism and another in the same age group. Measurement of PEM aimed to find out the special trait and relationship of variation of subpopulation PEM in a stock of marine biota population. The size of the PEM was of absolute size and the size ratio depends on the purpose of measurement. The PEM in this study based on binary, ordinal and numerical data types.

The PEM of MRC Based on Binary Data Type: PEM for binary data types obtained the distribution of various resemblance values with the highest coefficient values in the range of 0.85 to 0.89 found in subpopulation subadult on Ambon Island in 2013 and the juvenile on Ambon Island in 2014 (Figure 4).

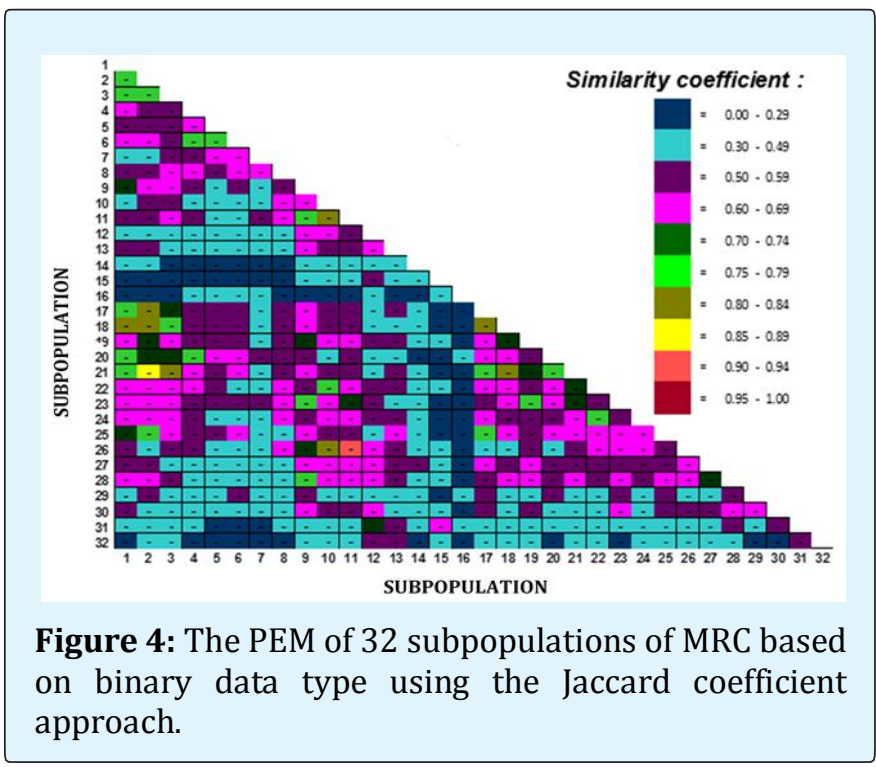

Similarities between 32 subpopulations dominated in the similarity coefficients of 0.30 to 0.49 as 166 of 496 subpopulations combination pairs (33.5\%). These results show that similarity PEM of MT was quite varied between 32 subpopulations when it has standardized to the test trait means the similarity level of expression of MT among subpopulations studied was not equal to one hundred percent. This result was interesting because the numerical approach could illustrate the proportion of morphometric ratio expression by each subpopulation to mode ratio to show the phenetic differences between the subpopulations.

The PEM of MRC based on ordinal data type: The PEM for ordinal data type obtained a range of values also varied. The highest correlation coefficient in the range of 0.80 to 0.84 found in 4 subpopulation pairs namely subadult on Ambon Island in 2015 and adult on Ambon Island in 2015, sub adult on Ambon Island in 2015 and subadult on Ambon Island in 2015, sub adult on Ambon Island in 2013 and subadult on Ambon Island in 2013, and the subadult of Ambon Island in 2013 and the juvenile on Ambon Island in 2014 (Figure 5).

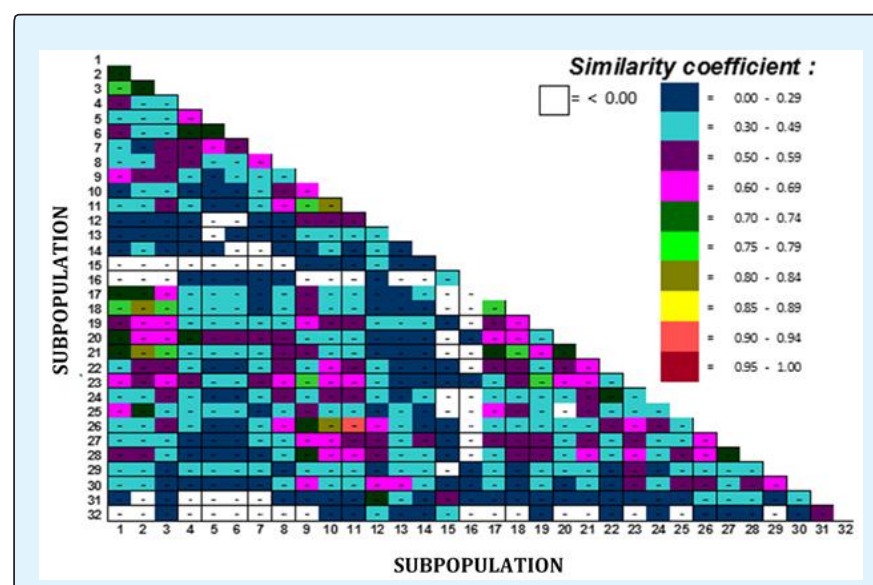

Figure 5: The PEM of 32 subpopulations of MRC based on ordinal data type using the Jaccard coefficient approach.

There was also a negative correlation coefficient value or less than 0.00 . These results indicate that the overall level of similarity phenotypic expression morphometric quite varied between subpopulation pairs even though it has been standardized to the trait of the test means that the unequal morphometric ratio values among subpopulations studied. These results illustrate the difference of the expression proportion to the interval of morphometric ratios used as test traits for each 


\section{International Journal of Oceanography \& Aquaculture}

subpopulation to show the phenotypic differences between the subpopulations.

The PEM of MRC Based on Numeric Data Type: PEM for numerical data type was quite homogeneous with only three correlation coefficient ranges of 0.60 to 0.69 as many as $40(8.1 \%)$ subpopulation pairs, 0.85 to 0.89 of 1 (0.2\%) subpopulation pairs and 0.95 to 1.00 as many as 455 (91.7\%) subpopulation pairs (Figure 6). This means the morphometric phenotypic expression for the numerical data type dominated at the coefficient of 0.95 to 1.00. These results differ with binary and ordinal data types that tend to be very varied meaning that phenotypic similarity for numeric data types describes the very high similarity between subpopulation pairs, which was above $95 \%$ when compared with binary and ordinal data types.

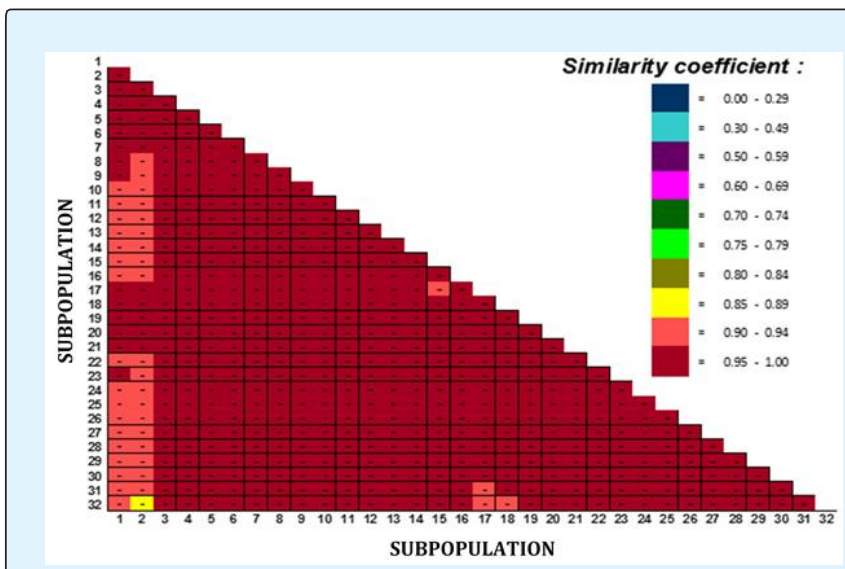

Figure 6: The PEM of 32 subpopulations of MRC based on numeric data type using the Jaccard coefficient approach.

The PEM based on binary, ordinal or numerical data types, may indicate that 32 subpopulations of the MRC was varied phenotypic similarities for both binary and ordinal data types, while quite homogeneous for numerical data types. The difference in the proportion of MT expression indicates that there was a difference of PEM developmental stage and shell growth, lifetime and geographical location. In addition, the PEM as a quantitative trait was polygenic and strongly influenced by the environmental factors in which it lives. However, from 32 subpopulations based on lifetime, the geographical location and shell development stages are sufficiently consistent and could illustrate the difference of PEM to the morphometric ratio for each subpopulation. Thus it could say that MRC was qualitative or morphological traits have the same PEM, but there were variations in quantitative or MT. The results of this study also indicated that each individual MRC had a unique phenotypic similarity and was not one hundred percent similar when done in detail and comprehensive approach based on three types of MT data.

\section{The Morphometric Taxa Level of 32 sub- populations of the MRC}

The MTL was the level of trait performance associated with variations and changes in the size of the body's shape and structure of the organism. Each individual has a specific and different size between one organism and another in the same age group. The MTL based on a set of measurement data representing a variety of shapes and sizes of the biota. In this study, the MTL among 32 subpopulations of the MRC determined based on binary, ordinal and numerical data types.

The MTL of 32 sub-populations of the MRC based on binary data type: The MTL based on the binary data type (Figure 7) shows the MTL on the similarity of $70 \%$ of the 17 phenotypic taxa. A taxa level of $80 \%$ similarity formed in 27 taxa, whereas at the similarity level of $90 \%$ no single pair of 32 subpopulations had a similarity above $90 \%$. These results indicated that there was a degree of variation of PEM of each subpopulation to the mode value of the constructed test trait. The $84 \%$ Cophenetic correlation shows $\mathrm{R}$ value greater than $60 \%$ [20], this means that the results of the calculations show valid or reliable results.

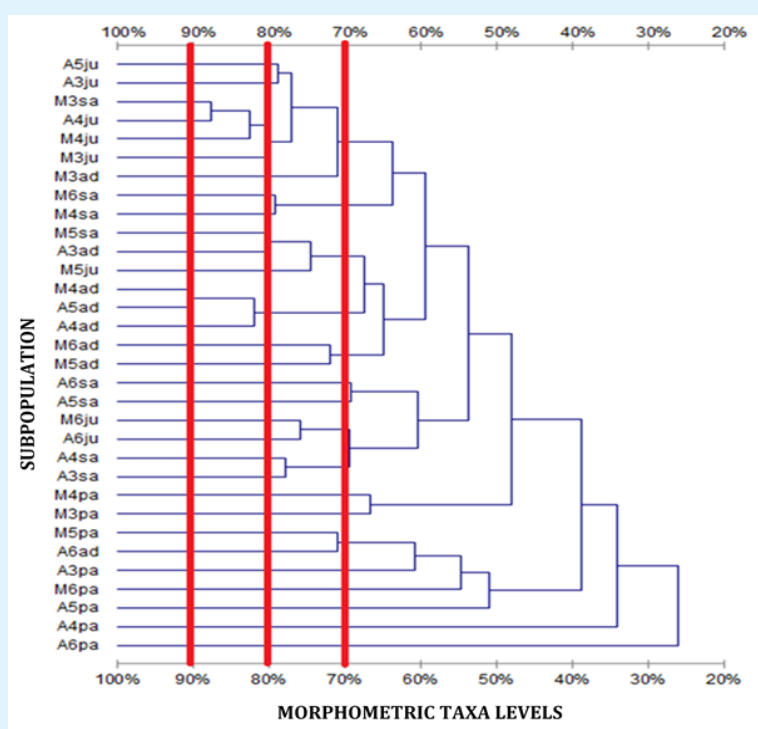

Figure 7: The MTL among 32 subpopulations of MRC based on binary data types; clustering using the UPGMA method using the Jaccard coefficient approach. 
The MTL of 32 sub-populations of the MRC based on ordinal data type: The MTL for the ordinal data type (Figure 8) shows that the MTL in the 0.900 correlation formed 31 taxa, meaning there were 2 subpopulations that have similarities above $90 \%$ i.e. adult on MTB Island in 2014 and the adult on Ambon Island in 2015. This was interesting because these two subpopulations come from different geographic locations, at different times and in the same stage of development, could have similar PEM above $90 \%$. The MTL in taxonomic correlation 0.800 formed 29 taxa, meaning there were group which have phenotypic similarity expression above $80 \%$ that first group consist of subpopulation adult on Ambon Island in 2015, adult on MTB Island in 2014 and adult on Ambon Island in 2014, and the second group was subpopulation of the subadult on MTB Island in 2013 and adult of Ambon Island 2014. These results could illustrate that the consistency of PEM between subpopulations once in different environment, time and stages of development. The MTL at 0.700 correlation formed 19 taxa. These results indicated that 32 subpopulations of MRC had a low correlation level under $70 \%$ even though the taxonomy and biological classification were still in one species.

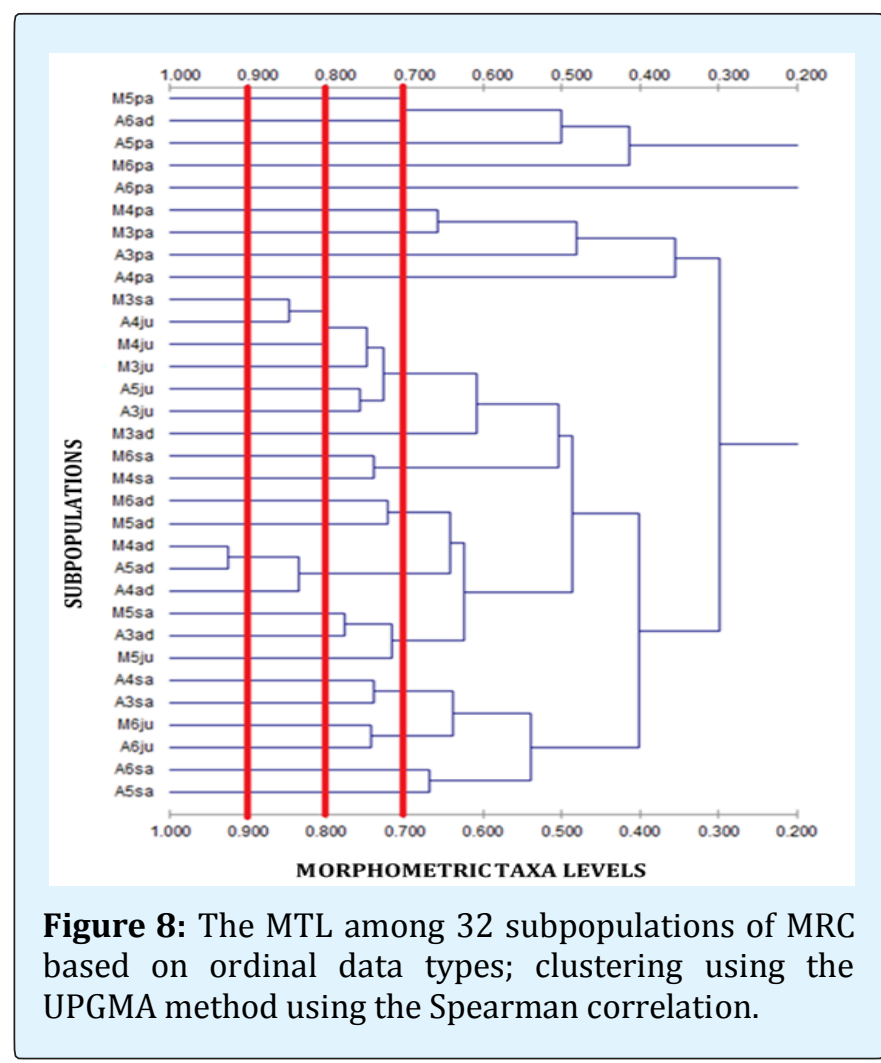

The MTL of 32 sub-populations of the MRC based on numeric data type: The MTL for the numerical data type
(Figure 9) shows that the MTL at 0.970 correlation forms one taxon. The MTL at 0.980 correlation formed two taxa, while at correlation level 0.985 formed three morphometric taxa. These results indicate that 32 subpopulations of Cypraea annulus for numerical data types have a very high degree of correlation of 0.970 or $97 \%$ because they were still in one taxon. Yet at a correlation level above 0.980 formed over two taxa or even 3 different taxa means that this numerical data type approach could separate the intra-species taxon, as compared with conventional models or morphological observations.

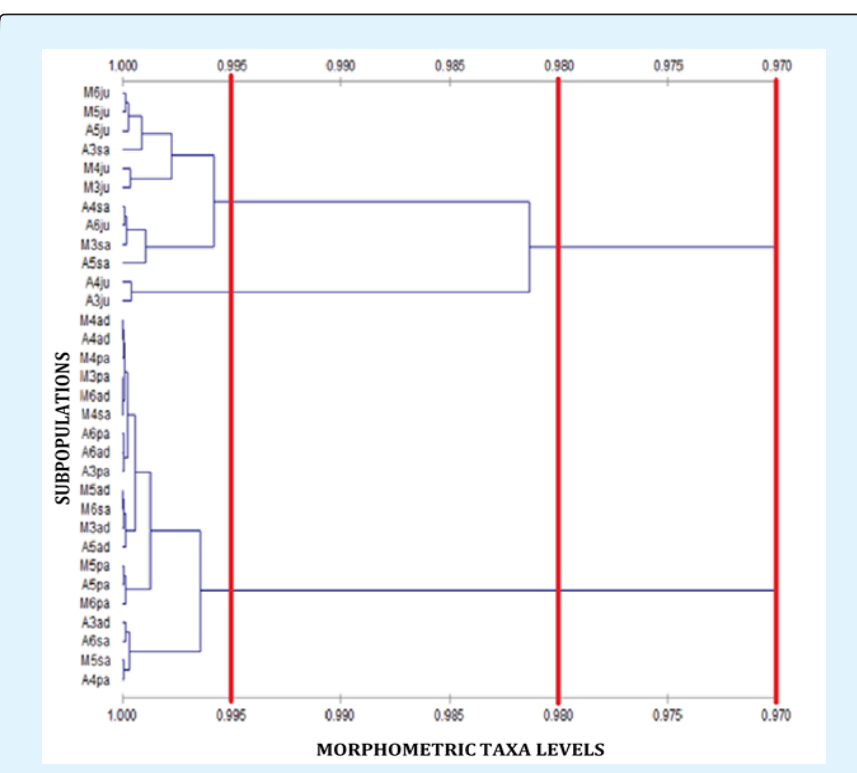

Figure 9: The MTL among 32 subpopulations of MRC based on ordinal data types; clustering using the UPGMA method using the Pearson correlation.

\section{The mapping of morphometric traits configuration 32 subpopulations of MRC}

The mapping of MTC aimed to describe the position of one subpopulation compared with other subpopulations. The presence of subpopulations in the same quadrant based on the similarity of the subpopulation, if two subpopulations have many similarities, then both will lie adjacent even in one ordinate with another in a particular quadrant. The MTC between 32 subpopulations of the MRC determined by binary, ordinal and numeric data types.

The Mapping of MTC 32 subpopulations of MRC based on binary data type: The analysis result of the deployment of 104 test traits obtained four trait classes 
owned by MRC shell of the first class consists of 19 traits, two trait class consists of 82 traits, the third trait class consists of one trait and the fourth trait class consists of two traits. The presence of MT classes in each subpopulation indicates that subpopulation distribution in the second trait class was more dominant than the first and third trait classes, whereas only sub-populations of subadult on MTB Island in 2013 included in the third trait class. Mapping of MTC 32 subpopulations based on test trait class for the binary data type, located at seven points or position spread over three quadrants (Figure 10). This showed that the MT of the binary data type has a quite different position between subpopulations with each other even though this subpopulation comes from the same location, time and life stage. The post-adult subpopulation MT of the Island of Ambon in 2013, subpopulation postadult on Ambon Island in 2014, subpopulation of adult on MTB Island in 2013 and subpopulation of subadult of MTB Island in 2016 have a high similarity because of its closed position and were in one quadrant, while postadult on MTB Island in 2014 and the subpopulation of adult on Ambon Island in 2016 had MT that was somewhat different from 30 other subpopulations because it has a far position and had somewhat different dimensions.

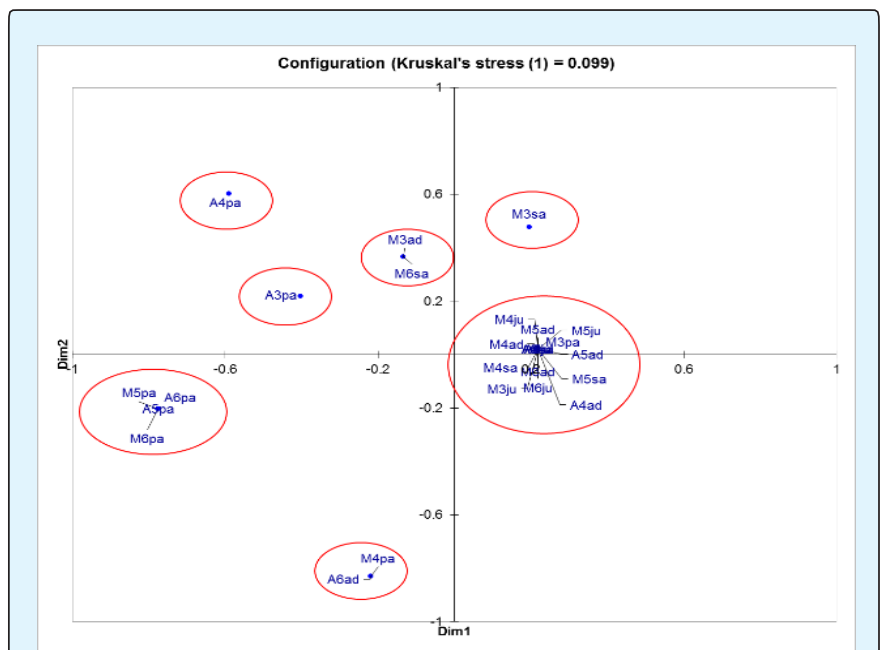

Figure 10: Map of the MTC for 32 subpopulations of MRC based on binary data type using multidimensional scaling methods.

The mapping of MTC 32 subpopulations of MRC based on ordinal data type: The result of spreading analysis of test trait for the ordinal data type obtained three trait class MRC that was first class consists of 80 traits, trait class two consist of 18 trait and third trait class consist of six traits. The existence of this trait class indicates that the distribution of subpopulations in the trait class was quite distributed and varied, but was still dominated by the second trait class. The MTC based on the MT class of the ordinal data type indicates that 32 subpopulation subpopulations were in seven dots or ordinate positions spread over three quadrants (Figure 11). These results indicated that the 32 subpopulations studied had quite different positions and distances between subpopulations with each other even though these subpopulations were from the same location, time and stages of life. Subpopulation traits of postadult on Ambon Island in 2013, subpopulation postadult on Ambon Island in 2014, subpopulation of adult on MTB Island in 2013 and subpopulation of sub adult of MTB Island in 2016 had a high similarity because its position was close and was in one quadrant, while subpopulation postadult on MTB Island in 2014 and subpopulation of adult on Ambon Island in 2016 had MT which was somewhat different from 30 other subpopulations because of its long-distance position and had somewhat different dimension, yet still one quadrant with subpopulation of subadult on MTB Island in 2013.

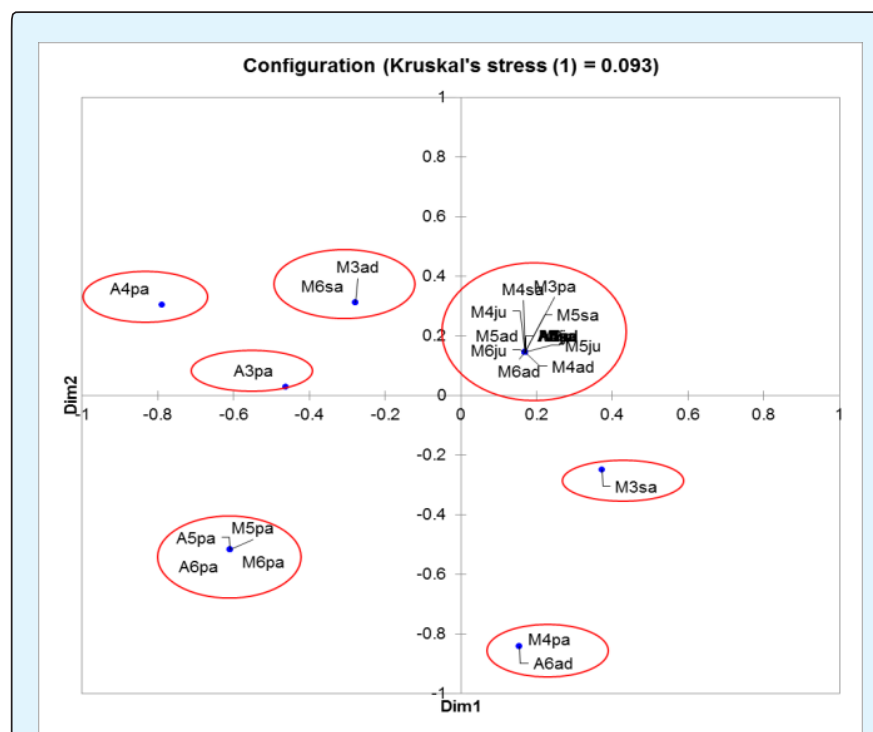

Figure 11: Map of the MTC for 32 subpopulations of MRC based on ordinal data type using multidimensional scaling methods.

The mapping of MTC 32 subpopulations of MRC based on numeric data type: The result of trait distribution analysis for the numerical data type formed three trait classes that was first trait class 61 trait, second trait class 32 trait and third trait class 11 trait. This result indicated 
that all subpopulations belong to the second and third trait classes, while the four subpopulations included in the first trait class. The map of MTC based on the trait class shows 32 subpopulations in two position points spread over two quadrants (Figure 12). These results indicated that 32 subpopulations studied have close positions and distances between subpopulations with each other. The subpopulation trait of postadult on Ambon Island in 2014, subpopulation of adult on MTB Island in 2013 and subpopulation postadult on MTB Island in 2016 had a very high similarity because being in the same position and quadrant means that these three subpopulations had MT somewhat different with 29 other subpopulations as they were in different positions and quadrants.

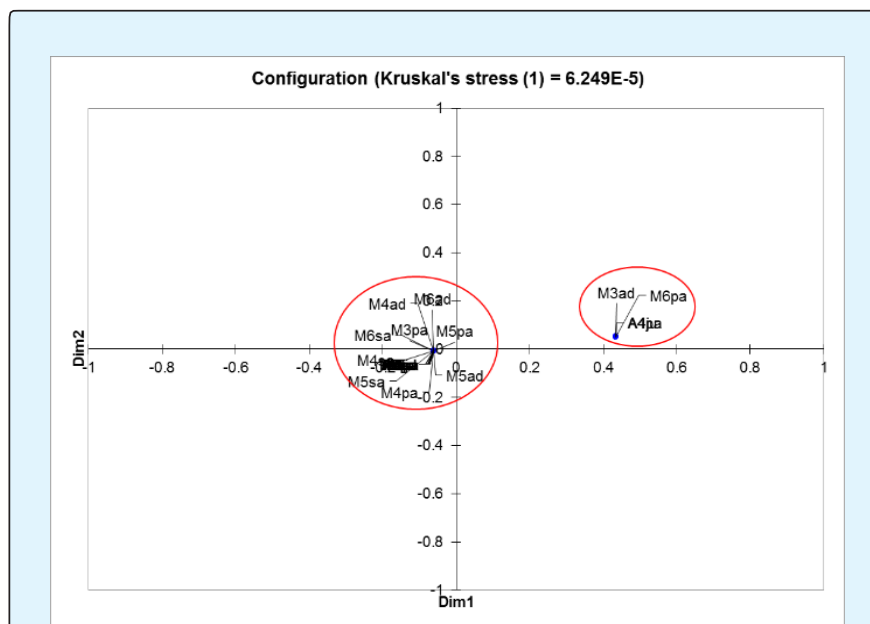

Figure 12: Map of the MTC for 32 subpopulations of MRC based on numeric data type using multidimensional scaling methods.

\section{Discussion}

\section{PEM as a Snail Response to its Environment}

This study obtained PEM among 32 subpopulations of diverse ring cowrie and not same one hundred percent the same for all three data types. PEM was the appearance of a trait possessed by individuals in the population. Several studies $[35,18,5]$ had also concluded that the diversity of organism traits such as morphology, anatomy, physiology, biochemistry, behavior, ecological and geological factors led to the appearance of different organisms' lifestyles. In the genetic concept, each species was a true population and each individual could mix with its species population. Previous research results $[4,5,65]$ had reported that this mixing leads to the emergence of phenotypic variation of individual traits and increases in proportion to the wider population distribution area. The results of this study proved that PEM among 32 subpopulations of MRC, with the same genetic material, do not appear too different individuals in the species population. The appearance of the trait influenced by environmental factors during the growth process and individual development. Individuals with similar genetic material may have different trait performance, not only in different individuals but also in different parts of the body in the same individual. Individuals in the juvenile period might differ from those of adults. Biota that lives and grow in enclosed areas may differ from those that live and thrive in open areas, even if the genotypes were the same.

Different patterns of phenotypes and genotypes would, of course, be difficult in determining species boundaries based on morphological traits, but were important in monitoring and evaluating trait performance on the basis of this pattern. It was in the opinion of other researchers $[9,16,57]$ that although the expression and performance of each trait of the biota vary, the performance of individual traits or species has a unique and specific pattern of order. By recognizing and analyzing this pattern of order, it could serve as the identity of individual traits in the species population. The identity of standardized traits in the trait performance index, it could use to monitor, evaluate and investigate the status and condition of the trait's performance at any time either to the genetic material, biota or ecology $[57,21]$.

\section{The MTL as a Result of Variation of Phenotypic Expression}

The MTL was the level of trait performance associated with variations and changes in the size of the body's shape and structure of the organism. The results of this study show that each individual in his subpopulation has a specific size and differences between one organism with another and even within the same age group. The MTL based on a set of measurement data representing a variety of shapes and sizes of the biota. In addition to different PEM, this study also obtained MTL of more than one at a $70 \%$ similarity level. Whereas in the classification and systematic 32 subpopulations belong to one species. The level of taxa that formed as a result of the variation in the expression of each individual in its subpopulation with different degrees. Other studies [4,12,20,63] also reported that the levels of taxa obtained could serve as basic information in the monitoring and evaluation of status and condition of genetic, biota and ecological performance. The individual's morphometric information could explain the status and performance conditions of an 


\section{International Journal of Oceanography \& Aquaculture}

individual in its species population. This trait performance index was important and fundamental as an indicator of biota trait performance in nature as well as cultured, as other researchers suggested $[55,57,58]$. Monitoring and evaluation of the status and condition of an individual or population need to carried out continuously or periodically to determine the condition of the biota whether the status or condition of performance was ideal or stable, degradation or decrease, and superior or hybrid [54,57]. The results of this study also indicate that each individual $M R C$ has a different MT performance, depending on geographical factors, age, and environmental circumstances. The spread and variation in the extent of the morphometric taxa that appears may be a response to the physical environment in which the species living.

Knowledge of the MTL in this study was fundamental and important because it has two benefits: practical and theoretical benefits. It was practically useful to evaluate and determine the degree of the taxon, biological status, and condition, whereas, theoretically, it could express the phylogenetic relationship of intraspecies and interspecies, as well as the possibility of changes in the quality of the biota and its environment. In addition, the MTL established could be used for detailed and thorough evaluation of 32 MRC subpopulations based on MT so that taxa were assigned to be key in monitoring and evaluation, selection and hybridization programs correctly. This was because the aquaculture system basically controls and manipulates the biota and its environment in a controlled system $[2,26,72]$. In the context of the efficiency and effectiveness of aquaculture production, it was necessary to monitor and evaluate the performance of the biota in order to obtain a track record and to know the advantages and disadvantages of the aquaculture process $[59,73,74]$. The use of morphometric variables has only recently been applied in the taxonomy of fish in the narrow sense of the method of fish identification, whereas the expression of the proportion of MT could be used in broader fields such as in the field of aquaculture for selection, hybridization, monitoring and performance evaluation of aquaculture biota. Therefore, an understanding of individual MTL in the population could be applied in monitoring and evaluation of biota performance among subpopulations, environmental and aquaculture systems, selection and hybridization programs, evaluating biota conditions and harvesting planning and even aquaculture biota quality.

\section{Mapping of MTC as a Visual Indicator of Proximity between Subpopulations}

The spread of the MT class that appears was a response to the physical environment in which the species live. The map of MTC could illustrate the proximity and similarity of trait classes between 32 subpopulations studied. Information on the spreading of MT classes could apply for broader purposes to map the traits in their classes to control biota performance between sub-patterns and as visual indicators of the proximity between subpopulations of biota in nature as well as in controlled units. The existence of a configuration pattern between trait classes becomes important in monitoring and evaluating the performance of traits on the basis of this pattern. Although the expression and performance of the traits of each biota were different, the performance of individual traits or species has a unique and specific pattern of order. Other previous studies $[11,42,57,28]$ also agree that the individual MT information could explain the status and performance conditions could even standardize into indexes of individual trait performance in the species population. The proximity map of similarities between sub-poles was also important and fundamental as an indicator of biota trait performance in nature as well as cultivated to know the condition among subpopulations in its population whether its performance was ideal or stable, degradation or decrease, and superior or hybrid.

\section{Conclusion}

This study concluded that PEM as the response of each individual snail to the population and its environment. There was a difference PEM of the shell of the shell of the shaft of both the developmental stages and the growth of the shell, lifetime and geographical location, although morpho-qualitatively or morphologically has the same phenotypic morphometric expression. Each individual of the MRC has a unique and there no one hundred percent unique phenotypic similarity when a detailed and comprehensive approach was made based on three types of MT data. The level of the taxa was formed as a result of variation PEM. The existence of different MTL in this study proved that the expression of the proportion of MT of MRC was strongly influenced by the environment, lifetime and life stages of snails. Mapping of MTC of the MRC illustrated the proximity of similar expressions between 32 subpopulations even though they lived in different geographical locations, lifetimes and stages of life development. 


\section{International Journal of Oceanography \& Aquaculture}

\section{References}

1. Beaumont AR, Boudry P, Hoare K (2010) Biotecnology and genetics in fisheries and aquaculture. $2^{\text {nd }}$ (Edn.), John Willey \& sons, UK.

2. Benzie JAH (2002) Genetics in aquaculture VII. Elsevier, Amsterdams.

3. Wagner GP (2001) The trait concept in evolutionary biology. Academic Press, San Diego.

4. Prendini L (2001) Species or supra specific taxa as terminals in cladistic analysis? Ground plans versus exemplars revisited. Systematic Biology 50: 290-300.

5. Sanmartin I, Ronquist F (2002) New solutions to old problems: Widespread taxa, redundant distributions and missing areas in event-based biogeography. Animal Biodiversity and Conservation 25(2): 75-93.

6. Taran G, Kluge AG (2004) Transformation Series as an Ideographic Trait Concept. Cladistics 20: 23-31.

7. Wagner PJ (2000) Exhaustion of morphologic trait states among fossil taxa. Evolution 54: 365-386.

8. Wagner PJ (2001) Rate heterogeneity in shell trait evolution among lophospirioid gastropods. Paleobiology 27: 290-310.

9. Schander C, Sundberg P (2001) Useful traits in gastropod phylogeny: soft information or hard facts? Systematic Biology 50: 136-141.

10. Scotland RW (2000) Taxic homology and three-taxon statement analysis. Systematic Biology 49(3): 480500 .

11. Sokal RR, Rohlf FJ (1995) Biometry: The Principles and Practice of Statistics in Biological Research. 3 ${ }^{\text {rd }}$ (Edn.), WH Freeman and Co., New York.

12. Smirnov ES (1969) Taxonomic Analysis. Moscow: State University of Moscow.

13. Walker JA (2000) Ability of geometric morphometric methods to estimate a known covariance matrix. Syst Biol 49(4): 686-696.

14. Wheeler QD (2002) Trait weighting and cladistic analysis. Systematic Zoology 35: 110-123.
15. Roth NAG, Grimm G, Mosbrugger V, Hass H, Kerp H (2000) Morphometric analysis of Rhynia and Asteroxylon: testing functional aspects of early land plant evolution. Paleobiology 26: 405-418.

16. Smith ND, Turner AH (2005) Morphology's role in phylogeny reconstruction: Perspectives from paleontology. Systematic Biology 54: 166-173.

17. Falica BK, Lehnert SJ, Pitcher TE, Daniel D Heath, Dennis M Higgs (2017) Ontogentic shifts in genetic and maternal effects on length and survival in Chinook salmon (Oncorhynchus tshawytscha). Aquaculture 468: 218-225.

18. Monteiro LR (2000) Why morphometrics is special: the problem with using partial warps as traits for phylogenetic analysis. Systematic Biology 49: 796800.

19. Wheeler QD (2007) Digital innovation and taxonomy's finest hour. In Automated Taxon Identification in Systematics: Theory, Approaches and Applications N MacLeod., CRC Press, Boca Raton, FL, pp: 9-23.

20. Sokal RR, Sneath PHA (1973) Numerical Taxonomy. The principles and practice of numerical classification. London, Freeman, pp: 573.

21. Premachandra HKA, Nguyen NH, Miller A (2017) Genetic parameter estimates for growth and nongrowth traits and comparison of growth performance in sea cages vs land tanks for yellowtail kingfish Seriola lalandi. Aquaculture 479: 169-175.

22. Rohlf FJ (2001) Comparative methods for the analysis of continuous variables: geometric interpretations. Evolution 55: 2143-2160.

23. Shoemaker CA, Lozano CA, La Frentz BR, García JC, Esteban Soto, et al. (2017) Additive genetic variation in resistance of Nile tilapia (Oreochromis niloticus) to Streptococcus iniae and S. agalactiae capsular type Ib: Is genetic resistance correlated? Aquaculture 468: 193-198.

24. Slice DE (2001) Landmark coordinates aligned by procrustes analysis do not lie in Kendall's shape space. Systematic Biology 50: 141-149.

25. Wiens JJ (2001) Trait analysis in morphological phylogenetics: problems and solutions. Systematic Biology 50: 689-699. 


\section{International Journal of Oceanography \& Aquaculture}

26. Laimeheriwa BM (2018) The Genetic Research Methods and its Role in Aquaculture on Indonesia. Int J Oceanogr Aquac 2(3): 1-23.

27. Janssen K, Chavanne H, Berentsen P, Komen H (2017) Impact of selective breeding on European aquaculture. Aquaculture 472: 8-16.

28. Lyu D, Wang W, Luan S, Yulong Hu, Jie Kong (2017) Estimating genetic parameters for growth traits with molecular relatedness in turbot (Scophthalmus maximus, Linnaeus). Aquaculture 468: 149-155.

29. Burgess CM (1985) Cowries of the world. Seacomber Publications, Cape Town.

30. Hughes L (2011) Cypraea annulus (Linnaeus 1758). Gold ring cowry.

31. Lorenz F, Hubert A (2000) A guide to worldwide cowries. Conch Books, Hackenheim.

32. Foin TC (1989) Significance of Shell Thickness in Cowries (Mesogastropoda : Cypraeidae). Bulletin of Marine Science 45(2): 505-518.

33. Orr V (1959) A bionomic shell study of Monetaria annulus (Gastropoda: Cypraeidae) from Zanzibar: Notulae Naturae of the Academy of Natural Sciences of Philadelphia 313: 1-11.

34. Irie $\mathrm{T}$ (2006) Geographical variation of shell morphology in Cypraea annulus Gastropoda: Cypraeidae. Journal of Molluscan Studies 72(1): 3138.

35. Irie T, Morimoto N (2008) Phenotypic plasticity and sexual dimorphism in size at post-juvenile metamorphosis: common-garden rearing of an intertidal gastropod with determinate growth. Biol Bull 215: 126-134.

36. Katoh M (1989) Life history of the golden ring cowry Cypraea annulus (Mollusca: Gastropoda) on Okinawa Island, Japan. Marine Biology 101(2): 227-234.

37. Meyer CP (2003) Molecular systematics of cowries Gastropoda: Cypraeidae. and diversifi cation patterns in the tropics. Biological Journal of the Linnean Society 79(3): 401-459.

38. Meyer CP, Paulay G (2014) Cowrie Genetic Database Project.
39. Lorenz F (2005) Taxonomic notes on two poorly known species of Notocypraea Gastropoda: Cypraeidae. Visaya 15: 16-21.

40. Ossorio C, Donald B, Atan H (1999) Aspect of the Reproductive Actifity of Cypraea caputdraconis from Easter Island ( Mollusca : Gastropoda : Cypraeidae). Pacific Science 53(1): 15-23.

41. Villamor S, Yamamoto $\mathrm{T}$ (2015) Reproductive seasonality of Monetaria annulus Linnaeus, 1758. Mollusca: Gastropoda: Cypraeidae. In a temperate area. Molluscan Research 352: 95-101.

42. Renaud ML (1971) Aspect of Biology and Ecology of Cypraea moneta at Eniwetok Atoll, Marshal Island. University of Hawaii, Honolulu, Hawai, USA.

43. Griffiths R (1961) Sexual dimorphism in Cypraeidae. Journal of Molluscan Studies 34: 203-206.

44. Schilder F, Schilder M (1961) Sexual differences in cowries. Journal of Molluscan Studies 34(4): 207-209.

45. Hayes $\mathrm{T}$ (1983) The influence of diet on local distributions of Cypraea. Pacific Science 37(1): 27-36.

46. Irie T, Adams B (2007) Sexual dimorphism in soft body weight in adult Monetaria annulus Family Cypraeidae. The Veliger 49(3): 209-211.

47. Villamor S (2012) Spatial and seasonal distribution of Cypraea annulus Mollusca: Gastropoda. In Hanazesaki, Ibusuki, Kagoshima Prefecture, Graduate School of Fisheries, Kagoshima University, Japan.

48. Irie T, Iwasa Y (2003) Optimal growth model for the latitudinal cline of shell morphology in cowries (genus Cypraea). Evolutionary Ecology Research 5(8): 1133-1149.

49. Wilson BR (1985) Direct Development in Southern Australian Cowries (Gastropoda: Cypraeidae).

50. Zahida F (2013) Perkiraan rentang hidup dan pola osilasi populasi Cypraea annulus Linnaeus, 1758, dari pantai Sepanjang, Yogyakarta.

51. Laimeheriwa BM, Khouw AS, Natan YL, Hiarihey J (2018a) Phenotypic classification of MRC, Cypraea annulus linn., 1758 (gastropod: cypraeidae), based on shell meristical. J Aquac Mar Biol 7(2): 80-90. 


\section{International Journal of Oceanography \& Aquaculture}

52. Laimeheriwa BM, Khouw AS, Natan YL, Limmon GV (2018b) The Role of Biomarker as a Taxonomic Material and Indicator of Traits Performance on Marine Biota. J Marine Sci Res Dev 8: 249.

53. Acacia Alcivar-Warren, Standish Allen, Rafet AlTobasei, Lisui Bao, Ben Beck, et al. (2017) Aquaculture genomics, genetics and breeding in the United States: Current status, challenges, and priorities for future research. BMC Genomics 18: 191.

54. Correa K, Bangera R, Figueroa R, Lhorente JP, Yáñez JM (2017) The use of genomic information increases the accuracy of breeding value predictions for sea louse (Caligus rogercresseyi) resistance in Atlantic salmon (Salmo salar). Genet Sel Evol 49: 15.

55. Farías WJ, Winkler FM, Brokordt KB (2017) Genotype by environment interactions, heritabilities and genetic correlations for productive traits of Haliotis rufescens. Aquaculture 473: 407-416.

56. Henriksson PJG, Dickson M, Allah AN (2017) Benchmarking the environmental performance of best management practice and genetic improvements in Egyptian aquaculture using life cycle assessment. Aquaculture 468: 53-59.

57. Hillen JEJ, Coscia I, Vandeputte M, Herten K, Hellemans B, et al. (2017) Estimates of genetic variability and inbreeding in experimentally selected populations of European sea bass. Aquaculture 479: 742-749.

58. Smith EN, Gutberlet RL (2001) Generalized frequency coding: a method of preparing polymorphic multistate traits for phylogenetic analysis. Systematic Biology 50(2): 159-169.

59. Vandeputte M, Puledda A, Tyran AS, Anastasia Bestin, Céline Coulombet, et al. (2017) Investigation of morphological predictors of fillet and carcass yield in European sea bass (Dicentrarchus labrax) for application in selective breeding. Aquaculture 470: 40-49.

60. Barros J, Velasco LA, Winkler FM (2018) Heritability, genetic correlations and genotype by environment interactions in productive traits of the Caribbean scallop, Argopecten nucleus (Mollusca: Bivalvia). Aquaculture 488: 39-48.
61. Zwickl DJ, Hillis DM (2002) Increased taxon sampling greatly reduces phylogenetic error. Syst Biol 51(4): 588-598.

62. Gurney-Smith HJ, Wade AJ, Abbott CL (2017) Species composition and genetic diversity of farmed mussels in British Columbia, Canada. Aquaculture 466: 33-40.

63. Laimeheriwa, M.B., (2017) Phenetic Relationship Study of Gold Ring Cowry, Cypraea annulus (Gastropods: Cypraeidae) in Mollucas Islands Based on Shell Morphological. Fish Aqua J 8: 215.

64. Iri T, Morimoto N (2016) Intraspecific variations in shell calcification across thermal windows and within constant temperatures: Experimental study on theintertidal gastropods Monetaria annulus. Journal of Experimental Marine Biology and Ecology 483: 130-138.

65. Dunn G, Everitt BS (1982) An Introduction to Mathematical Taxonomy. Cambridge Univ Press.

66. Zar JH (1999) Biostatistical analysis. 4th (Edn.), Prentice Hall, New Jersey.

67. Everitt BS (1978) Graphical Techniques for Multivariate Data. London, Heinemann.

68. Everitt BS (1980) Cluster Analysis. 2 ${ }^{\text {nd }}$ (Edn.), London, Heinemann.

69. Hair JF, Black BJ, Babin RE, Tatham RL (2006) Multivariate data analysis. $6^{\text {th }}$ (Edn.), Pearson Education Inc., New Jersey.

70. Johnson RA, Wichern DW (2002) Applied multivariate statistical analysis, $5^{\text {th }}$ (Edn.), Pearson Education, Inc., New Jersey.

71. Kruskal JB, Wish M (1978) Multidimensional Scaling. California, Sage.

72. Nolasco-Alzaga HR, Perez-Enriquez R, Enez F, Anastasia Bestin, Elena Palacios-Mechetnov, Pierrick Haffray (2018) Quantitative genetic parameters of growth and fatty acid content in the hemolymph of the Whiteleg shrimp Litopenaeus vannamei. Aquaculture 482: 17-23.

73. Wu D, Zhou L, Gao M, Mengying Wang, BingWang, et al. (2018) Effects of stickwater hydrolysates on growth performance for yellow catfish (Pelteobagrus fulvidraco). Aquaculture 488: 161-173. 


\section{International Journal of Oceanography \& Aquaculture}

74. Yıldız M, Eroldoğan TO, Ofori-Mensah S, Kenan Engin, Ali Baltacl M (2018) The effects of fish oil replacement by vegetable oils on growth performance and fatty acid profile of rainbow trout: Re-feeding with fish oil finishing diet improved the fatty acid composition. Aquaculture 488: 123-133.

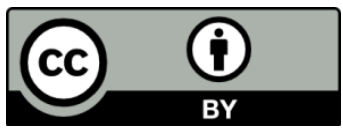

